\title{
Synthesis, characterisation and DNA intercalation studies of regioisomers of ruthenium (II) polypyridyl complexes
}

\author{
Laura Perdisatt \\ Technological University Dublin, laura.perdisatt@gmail.com \\ Samar Moqadasi \\ Technological University Dublin \\ Luke O'Neill \\ Technological University Dublin, Luke.oneill@tudublin.ie
}

See next page for additional authors

Follow this and additional works at: https://arrow.tudublin.ie/scschcpsart

Part of the Biochemistry Commons, Chemistry Commons, and the Food Science Commons

\section{Recommended Citation \\ Laura Perdisatt, Samar Moqadasi, Luke O'Neill, Gary Hessman, Alessandra Ghion, Muhammad Qasim Mushtaq Warraich, Alan Casey, Christine O'Connor, Synthesis, characterisation and DNA intercalation studies of regioisomers of ruthenium (II) polypyridyl complexes, Journal of Inorganic Biochemistry, Volume 182, 2018, Pages 71-82, ISSN 0162-0134, DOI: 10.1016/j.jinorgbio.2018.01.018.}

This Article is brought to you for free and open access by the School of Chemical and Pharmaceutical Sciences at ARROW@TU Dublin. It has been accepted for inclusion in Articles by an authorized administrator of ARROW@TU Dublin. For more information, please contact arrow.admin@tudublin.ie, aisling.coyne@tudublin.ie, gerard.connolly@tudublin.ie.

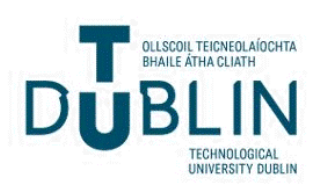




\section{Authors}

Laura Perdisatt, Samar Moqadasi, Luke O'Neill, Gary Hessman, Alessandra Ghion, Muhammad Qasim Mushtaq Warraich, Alan Casey, and Christine O'Connor 


\title{
Synthesis, characterisation and DNA intercalation studies of regioisomers of ruthenium (II) polypyridyl complexes
}

\author{
Laura Perdisatt ${ }^{\mathrm{a}}$, Samar Moqadasi ${ }^{\mathrm{a}}$, Luke O'Neill ${ }^{\mathrm{b}}$, Gary Hessman ${ }^{\mathrm{c}}$, Alessandra Ghion ${ }^{\mathrm{d}}$, \\ Muhammad Qasim Mushtaq Warraich ${ }^{\mathrm{d}}$, Alan Casey ${ }^{\mathrm{b}}$, Christine O'Connor ${ }^{\mathrm{d}, *}$ \\ ${ }^{a}$ FOCAS Research Institute/School of Chemical and Pharmaceutical Sciences, Dublin Institute of Technology, Kevin St, Dublin 8, Ireland \\ ${ }^{\mathrm{b}}$ School of Physics, Clinical and Optometric Science, Dublin Institute of Technology, Kevin St, Dublin 8, Ireland \\ ${ }^{\mathrm{c}}$ School of Chemistry, Trinity College, Dublin 2, Ireland \\ ${ }^{\mathrm{d}}$ School of Food Science and Environmental Health, Dublin Institute of Technology, Cathal Brugha St, Dublin 1, Ireland
}

\section{A R T I C L E I N F O}

\section{Keywords:}

Ruthenium (II) polypyridyl

Regioisomers

DNA \& cell-line studies

\begin{abstract}
A B S T R A C T
Regioisomers of the functional group of the main ligand (L) on a series of $\left[\mathrm{Ru}(\mathrm{phen})_{2} \mathrm{~L}\right]^{2+}$ and $\left[\mathrm{Ru}(\mathrm{bpy})_{2} \mathrm{~L}\right]^{2+}$ complexes, where phen is 1,10 phenanthroline and bpy is $2,2^{\prime}$-bipyridine, were synthesised to investigate the interaction with deoxyribonucleic acid (DNA) as potential therapeutics. UV-Vis binding titrations, thermal denaturation and circular dichroism were used to evaluate their interaction with DNA. The conclusions indicated the significance of the auxiliary ligand; especially 1,10-phenanthroline has on the binding constants $\left(\mathrm{K}_{\mathrm{b}}\right)$. The systematic variation of auxiliary ligand(phen or bpy), and polypyridyl ligand (4-(1H-Imidazo[4,5-f][1,10]phenanthrolin-2-yl)benzonitrile (CPIP), 2-(4-formylphenyl)imidazo[4,5-f] [1,10] phenanthroline (FPIP), 2-(4-bromophenyl)imidazo[4,5-f][1,10]phenanthroline (BPIP) and 2-(4-nitrophenyl)imidazo[4,5-f] [1,10] phenanthroline (NPIP), split in terms of functional group change were investigated for DNA interaction. The CPIP analogues in particular were investigated for the regioisomerism (ortho, meta, para) effect of the nitrile group on the ligand. It was found that both the DNA interaction could be tailored through the systematic variation of the electronic nature of the individual auxiliary ligand and to a lesser extent the functional group and regioisomeric change. Preliminary cell line studies have been carried out to determine the selectivity of the complexes against cell lines such as A375 (Skin Cancer), HeLa (Cervical Cancer), A549 (Lung Cancer), Beas2B (Lung Normal Cell) and MCF-7 (Breast Cancer). Complexes which had strong DNA interactions in the binding studies have proven to be the most efficacious against certain cell lines. Establishing well-defined structure property relationships when looking at trends in spectroscopic properties and DNA binding will aid in the intelligent design of potential therapeutic complexes.
\end{abstract}

\section{Introduction}

The potential application of ruthenium (II) complexes as anticancer compounds is being widely explored $[1,2]$. This decade is also witnessing the advent of ruthenium (II) polypyridyl complexes entering clinical trials [3] and with many more showing promising biological properties [4-12]. The synthesis of a series of novel systematically varied ruthenium (II) complexes (Fig. 1), altered either by changing (i) the auxiliary ligands (1,10 phenathroline (phen) and 2,2'bipyridine (bpy)), (ii) by the end group substituent upon the polypyridyl main ligand ((1H-Imidazo[4,5-f][1,10]phenanthrolin-2-yl) benzonitrile (CPIP), 2-(4-formylphenyl)imidazo[4,5-f] [1,10] phenanthroline (FPIP), 2-(4-bromophenyl)imidazo[4,5-f][1,10]phenanthroline (BPIP) and 2-(4-nitrophenyl)imidazo[4,5-f] [1,10] phenanthroline (NPIP)) and (iii) by changing the position of the functional group on the CPIP ligand (regioisomers - para, meta, ortho). Synthetically modifying one variable upon the complex structure, allows the study of how these specific chemical functionalities influence the deoxyribonucleic acid (DNA) intercalating affinities. Table 1.0 shows a library of ligands and complexes both previously published and novel that were employed in this study.

The novel regioisomeric ligands; $p$-CPIP $m$-CPIP and $o$-CPIP, where the nitrile substituent changes position on a polypyridyl ligand structure ( $x=$ para, meta and ortho) allowed the synthesis of a further six novel complexes of the structure; $\left[\mathrm{Ru}(\mathrm{bpy})_{2} x-\mathrm{CPIP}\right]^{2+}$ and $[\mathrm{Ru}$ (phen) $)_{2} x$-CPIP $]^{2+}$. The literature based ligands FPIP, NPIP and $m$-FPIP allowed for synthesis of comparative literature based $\mathrm{Ru}(\mathrm{II})$ complexes; $\left[\mathrm{Ru}(\mathrm{bpy})_{2} p \text {-FPIP }\right]^{2+},\left[\mathrm{Ru}(\mathrm{bpy})_{2} p \text {-NPIP }\right]^{2+},\left[\mathrm{Ru}(\mathrm{phen})_{2} p \text {-FPIP }\right]^{2+},[\mathrm{Ru}$

\footnotetext{
* Corresponding author.

E-mail address: Christine.oconnor@dit.ie (C. O'Connor).
} 


\begin{tabular}{|c|c|c|c|}
\hline \multicolumn{2}{|c|}{ Abbreviations } & \multirow{2}{*}{\multicolumn{2}{|c|}{$\begin{array}{l}\mathrm{K}_{\mathrm{b}} \quad \text { binding constant } \\
\text { MALDI-TOF matrix-assisted laser desorption ionization time-of } \\
\text { flight }\end{array}$}} \\
\hline A375 & skin cancer cell line & & \\
\hline A549 & lung cancer cell line & MCF-7 & breast cancer cell line \\
\hline \multirow[t]{2}{*}{ APIP } & 2-(2-Aminophenyl)imidazo $\quad[4,5-f][1,10]$ phenanthroline & MLCT & metal to ligand charge transfer \\
\hline & Beas2B Lung normal cell line & MOPIP & 2-(4-methoxyphenyl)imidazo[4,5-f] $[1,10]$ phenanthro- \\
\hline BfipH & 2-(benzofuran-2-yl)imidazo[4,5-f] $[1,10]$ phenanthroline & & line \\
\hline BPIP & 2-(4-bromophenyl)imidazo[4,5-f] $[1,10]$ phenanthroline & MS & mass spectroscopy \\
\hline Bpy & $2,2^{\prime}$ bipyridine & MTT & 3-(4,5-dimethylthiazol-2-yl)-2,5-diphenyltetrazolium bro- \\
\hline Calc & calculated & & mide \\
\hline CT-DNA & calf thymus-DNA & NAMI & sodium trans-(dimethylsulfoxide)(imidazole)tetrachloro \\
\hline $\mathrm{CD}$ & circular dichroism & & ruthenate(III) \\
\hline CPIP & 2-(4-cyanophenyl)imidazo[4,5-f] $[1,10]$ phenanthroline & NMR & Nuclear Magnetic Resonance \\
\hline DBHIP & $\begin{array}{l}\text { 2-(3,5-dibromo-4-hydroxyphenyl)imidazo[4,5-f] }[1,10] \\
\text { phenanthroline }\end{array}$ & $\begin{array}{l}\text { NPIP } \\
\text { PBS }\end{array}$ & $\begin{array}{l}\text { 2-(4-nitrophenyl)imidazo[4,5-f] }[1,10] \text { phenanthroline } \\
\text { phosphate buffered saline }\end{array}$ \\
\hline DMSO & dimethylsulphoxide & Phen & 1,10 Phenanthroline \\
\hline DNA & deoxyribonucleic acid & Pip & 2-phenyl-imidazo[4,5-f]1,10-phenanthroline \\
\hline ES-MS & electrospray ionization mass spectroscopy & ppm & parts per million \\
\hline FBS & foetal bovine serum & RAP & dichloro-1,2-propylenediamine tetraacetate ruthenium \\
\hline FPIP & 2-(4-formylphenyl)imidazo[4,5-f] $[1,10]$ phenanthroline & & (III) \\
\hline HAPIP & $\begin{array}{l}\text { 2-(2-Hydroxyl-5-aminophenyl)imidazo }[4,5-\mathrm{f}][1,10]-\text { Phe- } \\
\text { nanthroline }\end{array}$ & $\begin{array}{l}\text { RPMI } \\
\text { TD }\end{array}$ & $\begin{array}{l}\text { Roswell Park Memorial Institute } \\
\text { thermal denaturation }\end{array}$ \\
\hline HeLa & cervical cancer cell line & $\operatorname{Tm}$ & melting temperature \\
\hline HPIP & 2-(4-hydroxyphenyl)imidazo[4,5-f] $[1,10]$ phenanthroline & $\mathrm{UV} / \mathrm{Vis}$ & ultraviolet/visible \\
\hline IC50 & half the maximal inhibitory concentration & & \\
\hline
\end{tabular}

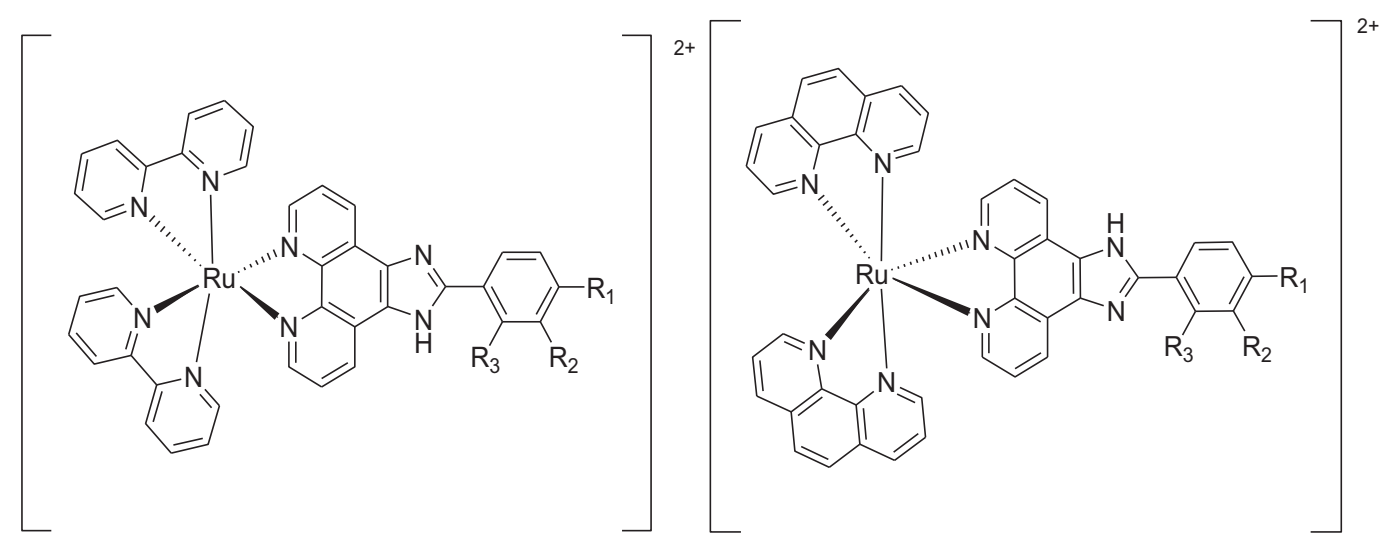

Fig. 1. Molecular structure of the ruthenium complexes where $\mathrm{R}$ is $(\mathrm{CHO}),\left(\mathrm{NO}_{2}\right),(\mathrm{Br})$ or $(\mathrm{CN})$ and $\mathrm{R}_{1}=$ para, $\mathrm{R}_{2}=$ meta, $\mathrm{R}_{3}=$ ortho positions.

(phen $)_{2} p$-BPIP $]^{2+}$ and $\left[\mathrm{Ru}(\text { phen })_{2} p \text { NPIP }\right]^{2+}[13-17]$. This study includes the synthesis of a series of ligands based on a 1,10-phenanthroline-5, 6-dione (phendione) backbone. The main strategy behind

Table 1

All the Ru(II) complexes synthesised within this study. Novel complexes highlighted with asterisk*.

\begin{tabular}{lllll}
\hline Complex & Ligand (L) & $\mathrm{R}_{1}$ & $\mathrm{R}_{2}$ & $\mathrm{R}_{3}$ \\
\hline$\left[\mathrm{Ru}(\mathrm{bpy})_{2} \mathrm{~L}\right]^{2+}$ & $p$-FPIP & $\mathrm{CHO}$ & $\mathrm{H}$ & $\mathrm{H}$ \\
$m$-FPIP & $\mathrm{H}$ & $\mathrm{CHO}$ & $\mathrm{H}$ \\
$p$-NPIP & $\mathrm{NO}_{2}$ & $\mathrm{H}$ & $\mathrm{H}$ \\
$p$-BPIP & $\mathrm{Br}$ & $\mathrm{H}$ & $\mathrm{H}$ \\
$p$-CPIP* & $\mathrm{CN}$ & $\mathrm{H}$ & $\mathrm{H}$ \\
$m$-CPIP* & $\mathrm{H}$ & $\mathrm{CN}$ & $\mathrm{H}$ \\
& $o$-CPIP* & $\mathrm{H}$ & $\mathrm{H}$ & $\mathrm{CN}$ \\
& $p$-FPIP & $\mathrm{CHO}$ & $\mathrm{H}$ & $\mathrm{H}$ \\
& $m$-FPIP & $\mathrm{H}$ & $\mathrm{CHO}$ & $\mathrm{H}$ \\
& $p$-NPIP & $\mathrm{NO} \mathrm{O}_{2}$ & $\mathrm{H}$ & $\mathrm{H}$ \\
& $p$-BPIP & $\mathrm{Br}$ & $\mathrm{H}$ & $\mathrm{H}$ \\
$p$-CPIP* & $\mathrm{CN}$ & $\mathrm{H}$ & $\mathrm{H}$ \\
& $m$-CPIP* $\left.]_{2}\right]^{2+}$ & $\mathrm{H}$ & $\mathrm{CN}$ & $\mathrm{H}$ \\
& $o$-CPIP* & $\mathrm{H}$ & $\mathrm{H}$ & $\mathrm{CN}$ \\
\hline
\end{tabular}

building these conjugated heteroaromatic ligands was to increase the binding ability of polypyridyl $\mathrm{Ru}(\mathrm{II})$ complexes with a pendant arm containing a second binding moiety with high affinity for DNA. Barton and co-workers synthesised novel metal complexes bearing at least one strongly intercalating ligand, i.e., metallointercalators containing an expanded aromatic heterocyclic ligand, which can readily allow stacking interactions within the DNA double helix $[2,18]$.

For the ruthenium anticancer complexes molecular mechanistic studies are only at the beginning [19]. Mechanistic studies on both platinum and ruthenium compounds have, however, opened many new avenues of research that may lead to the design of completely new drugs [19].A recent perspective article by Alessio et al., categorised metal anticancer compounds based on their mode of action, which could be divided into five different classes: 1 . The metal has a functional role, 2. The metal has a structural role, 3. The metal is a carrier for main ligands that are delivered in vivo. 4. The metal compound behaves as a catalyst in vivo, 5 . The metal compound is photoactive [20]. Elucidation and optimisation of the mode of action of anticancer agents in classes 2, 4, and 5 as defined by Alessio et al. require an intimate knowledge of both the structural and electronic properties of the complexes. Thus to fully realise the advantages of ruthenium 
complexes as novel inorganic therapeutics, it is crucial that the photophysical processes which govern the reactivity of the complexes are fully and comprehensively understood [20].

Many research teams have embraced the phen structure into the synthesis of a variety of planar polypyridyl ligands $[6,8,9]$ with different end group position in the phenyl ring, developed on from the planar ligand for example; 2-phenyl-imidazo[4,5-f]1,10-phenanthroline (PIP) consisting of the a basic phenyl ring [21]. Increasing the surface area of the phen polypyridyl ligand has seen to increase the DNA binding affinity of the complex [21]. Promising activity has been observed for these phen functionalised ligand as ruthenium based complexes, Li et al. synthesised a similar series of these style ligands; $p$ MOPIP with OMe group (2-(4-methoxyphenyl)imidazo[4,5-f] $[1,10]$ phenanthroline) ( $\mathrm{R}_{1}$ (para) position on the phenyl ring), $p$-HPIP with $\mathrm{OH}$ group2-(4-hydroxyphenyl)imidazo[4,5-f] [1,10] phenanthroline and $p$-NPIP with $\mathrm{NO}_{2}$ group (2-(4-nitrophenyl)imidazo[4,5-f] [1,10] phenanthroline) [10]. Antitumour activity was observed against L1210 cells, Human oral epidermoid carcinoma KB cells (HeLa cell derivative), human promyelocytic cells, HL-60 and Bel- 7402 cancer cells by MTT assay (3-(4,5-dimethylthiazol-2-yl)-2,5-diphenyltetrazolium bromide assay). Promising intercalative DNA binding ability and cytotoxic observations for these ruthenium based polypyridyl complexes indicate that modification of the ligands have led to subtle changes in their binding modes, location and affinities with DNA [ 22-24].

In more recent times a trend in medicinal chemistry has been a trend away from high-throughput approaches to drug discovery (i.e. those where vast databases of molecules are screened against a biological target) towards structure-based drug discovery (i.e. those where drug design is based on specific structural information about a biological target) [25]. The coordination compounds of $\mathrm{Ru}(\mathrm{II})$ were synthesised with the following nitrogen donor ligands; 2, 2'-bipyridine (bpy) and 1,10-phenanthroline (phen). The step-by-step substitution of the functional group on the polypyridyl ligand allows analysis with essentially a single variable, increasing the electron affinity of the terminal group on the polypyridyl ligand. The effect of the systematic change on the complexes properties is investigated using a series of ruthenium complexes with the end-group terminations varied from 2(4-formylphenyl)imidazo[4,5-f] $[1,10]$ phenanthroline [ $p$-FPIP], 2-(4cyanophenyl)imidazo[4,5-f] $[1,10]$ phenanthroline [p-CPIP], 2-(4-bromophenyl)imidazo[4,5-f] $[1,10]$ phenanthroline [p-BPIP], to 2-(4-nitrophenyl)imidazo[4,5-f] $[1,10]$ phenanthroline [p-NPIP]. The regioisomeric change was investigated for the complexes of the CPIP ligand.

\section{Experimental}

\subsection{Materials and methods}

Reagents and solvents were used without further purification and purchased from Sigma Aldrich and Fisher Scientific. 1,10-phenanthroline-5,6-dione was prepared by the procedure described by Zheng et al. [26] Synthesis of 2-(4-formylphenyl)imidazo[4,5-f] [1,10] phenanthroline ( $p$-FPIP) (also abbreviated to fmp)was prepared following the method reported by He et al. [ 17] Synthesis of 4-(1H-Imidazo[4,5-f] $[1,10]$ phenanthrolin-2-yl)benzaldehyde (m-FPIP) was synthesised in an identical manner as described for $p$-FPIP and by Chao et al. [14] Synthesis of 2-(4-nitrophenyl)imidazo[4,5-f] $[1,10]$ phenanthroline ( $p$ NPIP) was prepared in an identical manner as described for $p$-FPIP and by Liu et al. [15] Synthesis of 2-(4-bromophenyl)imidazo[4,5-f][1,10] phenanthroline ( $p$-BPIP) was synthesised in an identical manner as described for $p$-FPIP and by Sergeeva et al. [27]

The ligands were characterised by ${ }^{1} \mathrm{H},{ }^{13} \mathrm{C}$, COSY, HSQC, IR, Raman spectroscopy and elemental analysis. The experiments were carried out at room temperature $(300 \mathrm{~K})$. Absorption spectroscopy and luminescence measurements were performed on each polypyridyl ligand in ethanol at a concentration of $0.025 \mathrm{mM}$. A full vibrational study was completed employing IR and Raman spectroscopy on each ligand to fully characterise the molecular structure. Elemental analyses (CHN) were carried out by the Microanalytical Department, University College Dublin. MALDI-TOF mass spectroscopy was completed by the Mass Spectrometry Unit in Trinity College Dublin on the novel ligands.

The following ligands were prepared to investigate the regioisomers (ortho, meta, para) of the end group on the main ligand and to observe its effect on the DNA intercalating properties of the resulting ruthenium complexes.

\subsection{Synthesis of ligands}

\subsubsection{Synthesis of 4-(1H-Imidazo[4,5-f][1,10]phenanthrolin-2-yl) benzonitrile ( $p$-CPIP)}

The ligand was synthesised in an identical manner as described for $p$-FPIP by Liu et al. [15] with 4-formylbenzonitrile (314 mg, $2.5 \mathrm{mmol}$ ) in place of terephthalic aldehyde. Yield: $0.5115 \mathrm{~g}(63.6 \%) . \mathrm{v}\left(\mathrm{cm}^{-1}\right)$ $2226.6 \mathrm{~s}, 1611.1 \mathrm{~m}, 1553.0 \mathrm{~m}, 1480.6 \mathrm{~m}, 1397.8 \mathrm{~m}, 802.6 \mathrm{~s}$ and $737.9 \mathrm{~s}$. MALDI-TOF MS $(m / z)[M+H]^{+}$: Actual mass: 322.1096; Calculated mass: $322.1093 .{ }^{1} \mathrm{H}$ NMR (400 MHz, d 6 -DMSO) ppm: 9.0 (dd $2 \mathrm{H}$ $7,8 J=1.6,1.6,4,4), 8.91$ (dd $2 \mathrm{H} 5,10 J=2,1.6,8.4,8), 8.35$ (d, $2 \mathrm{H}, 3,11 J=8.4), 8.03(\mathrm{~d}, 2 \mathrm{H} 2,12 J=8.4), 7.78(\mathrm{dd} 2 \mathrm{H} 6,9 J=4.4$, $4.4,8,8) .{ }^{13} \mathrm{C}$ NMR (400 MHz, d 6 -DMSO) [ppm]: $148.6(\mathrm{C} 23,26)$, 148.17(C19,30), 143.84 (C24,25), 133.97 (C20, 29), 133.04(C15,32), 129.71 (C16,31), 126.61 (C21,28), 123.41(C22,27), 118.67 (C13) 111.42 (C14).

\subsubsection{Synthesis of 3-(1H-Imidazo[4,5-f][1,10]phenanthrolin-2-yl) benzonitrile (m-CPIP)}

The ligand was synthesised as described for $p$-CPIP with 3-formylbenzonitrile ( $156 \mathrm{mg}, 1.18 \mathrm{mmol}$ ) in place of 4-formylbenzonitrile. Yield: $0.245 \mathrm{~g} \mathrm{(64 \% ).} \mathrm{v}\left(\mathrm{cm}^{-1}\right) 2231.4 \mathrm{~s}, 1606.2 \mathrm{~m}, 1547.2 \mathrm{~m}$, $1471.2 \mathrm{~m}, 1400.3 \mathrm{~m}, 804.6 \mathrm{~s}$ and $736.3 \mathrm{~s}$. MALDI-TOF MS $(\mathrm{m} / \mathrm{z})$ $[\mathrm{M}+\mathrm{H}]^{+}$: Actual mass: 322.1098; Calculated mass: $322.1093 .{ }^{1} \mathrm{H}$

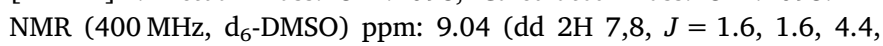
4.4), 8.87 (dd $2 \mathrm{H} 5,10 \mathrm{~J}=1.6,1.6,8,8), 8.61(\mathrm{~s}, 1 \mathrm{H}, 11), 8.56$ (d, $1 \mathrm{H}, 3$ ), 7.89 (d, $1 \mathrm{H} \mathrm{1}$ ), 7.77 (m 3H 2, 6, 9). ${ }^{13} \mathrm{C}$ NMR (400 MHz, d $6^{-}$ DMSO) [ppm]: 173.13(C18) 149.43 (C19,30), 147.54(C23,26), 143.49 (C24,25), 132.12 (C14), 130.45 (C16), 130.177 (C15), 129.56 (C21,28), 129.16 (C31), 123.17 (C22,27), 121.87(C20,29), 118.67(C13), 111.92(C32).

\subsubsection{Synthesis of 2-(1H-Imidazo[4,5-f][1,10]phenanthrolin-2-yl) benzonitrile (o-CPIP)}

The ligand was synthesised in an identical manner as described for p-CPIP with 2-formylbenzonitrile $(156 \mathrm{mg}, 1.18 \mathrm{mmol})$ in place of 4 formylbenzonitrile. Yield: $0.133 \mathrm{~g}(35 \%) . v\left(\mathrm{~cm}^{-1}\right) 2229.9 \mathrm{~s}, 1600.0 \mathrm{~m}$, $1569.6 \mathrm{~m}, 1481.6 \mathrm{~m}, 1399.9 \mathrm{~m}, 808.0 \mathrm{~s}$ and $737.4 \mathrm{~s}$. MALDI-TOF MS $(m / z)[\mathrm{M}+\mathrm{H}]^{+}$: Actual mass: 322.1092; Calculated mass: 322.1093. ${ }^{1} \mathrm{H}$ NMR (400 MHz, $\mathrm{d}_{6}$-DMSO) ppm: 9.04 (dd 2H 7,8 $\mathrm{J}=1.6,2$, 4, 4.4), 8.87 (dd $2 \mathrm{H} 5,10 J=1.6,2,8,8.4$ ), 8.33 (d, $1 \mathrm{H}, 3, J=7.8$ ), 8. 01 (d, $1 \mathrm{H}, 12, J=7.8$ ), 7.85 (d of t, $1 \mathrm{H}, 2 J=7.8,7.6$ ), 7.81 (m, 2H, 6,9) 7.63 (d of t, $1 \mathrm{H}, 1 J=7.6,7.6) .{ }^{13} \mathrm{C}$ NMR ( $400 \mathrm{MHz}, \mathrm{d}_{6}$-DMSO) [ppm]: 172.844(C18) 149.29 (C19,30), 147.48(C23,26), 143.52 (C24,25), 135.16 (C32), 133.71 (C20,29), 133.71 (C15), 129.73 (C21,28), 129.08 (C14), 128.75 (C16), 123.23(C22,27), 122.284 (C17),118.82(C13), 109.47(C31).

\subsection{Synthesis of complexes}

The general synthetic methods for the dichloride ruthenium complexes are well known and gave good yields [28]. All of the literature reference based complexes were prepared according to their literature methods. [13-16,29] $\left[\mathrm{Ru}(\mathrm{bpy})_{2} \text { FPIP }\right]^{2+}$ and $\left[\mathrm{Ru}(\mathrm{bpy})_{2} \mathrm{~m} \text {-FPIP }\right]^{2+}$ was prepared by Chao et al. $[13,14],\left[\mathrm{Ru}(\mathrm{bpy})_{2} \mathrm{NPIP}\right]^{2+}$ was prepared by Shuo et al. [29], [Ru(phen $\left.)_{2} p-\mathrm{NPIP}\right]^{2+}$ was prepared by Liu et al. [15], 
$\left[\mathrm{Ru}(\mathrm{phen})_{2} p\right.$-BPIP] ${ }^{2+}$ was prepared by Xu et al. [16]

\subsubsection{Synthesis of $\left[R u(b p y)_{2} p-C P I P\right]^{2+}$}

The complex was synthesised in an identical manner as described for $\left[\mathrm{Ru}(\mathrm{bpy})_{2} p \text {-FPIP }\right]^{2+}$ by Chao et al. [13], with $p$-CPIP $(0.080 \mathrm{~g}$, $0.3 \mathrm{mmol})$ replacing $p$-FPIP. Yield: $0.143 \mathrm{~g}(78 \%)$. Elemental analysis (\%) Calculated for $\left[\mathrm{Ru}\left(\mathrm{C}_{10} \mathrm{H}_{8} \mathrm{~N}_{2}\right)_{2}\left(p-\mathrm{C}_{20} \mathrm{H}_{11} \mathrm{~N}_{5}\right)\right]\left[\mathrm{PF}_{6}\right]_{2} \cdot 3\left(\mathrm{H}_{2} \mathrm{O}\right)$ : C 44.54, H: 3.08, N: 11.69; found C 44.46, H: 3.10, N: 11.42. ES-MS of the $\mathrm{PF}_{6}{ }^{-}$ salt $\left[\left(\mathrm{M}^{+}-\left(\mathrm{PF}_{6}\right)\right)\right]: m / z 880.2$ (calc 880.1 ) and 367.6 , resolution of the peak 367.6 shows the species is double charged and the isotope distribution corresponds to the calculated one. ${ }^{1} \mathrm{H}$ NMR $(400 \mathrm{MHz})$ in $\left(\mathrm{CD}_{3}\right)_{2} \mathrm{SO}$ ppm; 14.66 (1H, s, H16), 9.10 (2H, d, H11, 17, $\left.J=8.4\right), 8.88$ (4H, m, H 1, 8, 20, 27), 8.48 (2H, d, H12, 15), 8.23 (2H, t, H7, 21), 8.13 (6H, m, H13, 14, 2, 26, 9, 19), 7.96 (2H, t, H 10,18), 7.86 (2H, d, H5, 23), 7.61 (4H, m, H4, 24, 6, 22), 7.36 (2H, t, H 3, 25). ${ }^{13} \mathrm{C}$ NMR ppm; 156.72, 156.51, 151.47 (C 34, 61), 151.37 (C 31, 64), 150.21 (C 38, 57), 145.36, 137.96 (C 36, 59), 137.81 (C29, 66), 133.45\& 133.29 (C 47, 50), 130.49 (C 40, 55), 127.89 (C 35, 60), 127.72 (C 30, 65), 127.04 (C 46, 51), 126.50 (C39, 56), 124.44 \& 124.35 (C 28, 37, 58, 67), 118.51 (C49), 112.25 (C48).

\subsubsection{Synthesis of $\left[R u(b p y)_{2} m-C P I P\right]^{2+}$}

The complex was synthesised as described for $\left[\mathrm{Ru}(\mathrm{bpy})_{2} p-\mathrm{FPIP}\right]^{2+}$ with $m$-CPIP $(0.080 \mathrm{~g}, 0.3 \mathrm{mmol})$ replacing $p$-FPIP. Yield: $0.139 \mathrm{~g}$ (76\%). Elemental analysis (\%) Calculated for $\left[\mathrm{Ru}\left(\mathrm{C}_{10} \mathrm{H}_{8} \mathrm{~N}_{2}\right)_{2}(m-\right.$ $\left.\left.\mathrm{C}_{20} \mathrm{H}_{11} \mathrm{~N}_{5}\right)\right]\left[\mathrm{PF}_{6}\right]_{2} \cdot 2\left(\mathrm{H}_{2} \mathrm{O}\right): \mathrm{C} 45.29, \mathrm{H}: 2.95$, N: 11.88; found C 45.01, H: 2.65, N: 11.80. MALDI-TOF: $(\mathrm{m} / \mathrm{z}):[\mathrm{M}-\mathrm{H}]^{+}$Actual mass: 734.1388; Calculated mass: $734.1355 .{ }^{1} \mathrm{NMR}(400 \mathrm{MHz})$ in $\left(\mathrm{CD}_{3}\right)_{2} \mathrm{SO} \mathrm{ppm} ; 14.7$ (1H, s, H16), 9.06 (2H, d, H11, 17, $J=8.4$ ), 8.88 (4H, m, H 1, 8, 20, 27), 8.67 (1H, s, H15), 8.62 (1H,d, H12), 8.23 ( $2 \mathrm{H}, \mathrm{d}, \mathrm{H} 7,21, J=8$ ), 8.10 (5H, m, H14, 2, 26, 9, 19), 7.91 (5H, m, H13, 5, 23, 10, 18), 7.61 (4H, m, H 4, 24, 6, 22), 7.35 (2H, t, H 3, 25). ${ }^{13} \mathrm{C}$ NMR ppm; $156.72(\mathrm{Q})$, $156.51,151.46$ (C 34, 61), 151.36 (C 31, 64), 150.11 (C 38, 57), 145.24, 137.95 (C 36, 59), 137.80 (C 29, 66), 133.54 (C 48), 130.95 (C 46), 130.71 (C 47), 130.34 (C 40, 55), 129.65 (C 51), 127.88 (C 35, 60), 127.73 (C 30, 65), 126.46 (C 39, 56), $124.43 \& 124.35$ (C 28, 37, 58, 67), 118.29 (C49), 112.38 (C50).

\subsubsection{Synthesis of $\left[R u(b p y){ }_{2} O-C P I P\right]^{2+}$}

The complex was synthesised in an identical manner as described for $\left[\mathrm{Ru}(\mathrm{bpy})_{2} p-\mathrm{FPIP}\right]^{2+}$ with $o$-CPIP $(0.080 \mathrm{~g}, 0.3 \mathrm{mmol})$ replacing $p$ FPIP. Yield: $0.103 \mathrm{~g}(56 \%)$. Elemental analysis (\%) Calculated for [Ru $\left.\left(\mathrm{C}_{10} \mathrm{H}_{8} \mathrm{~N}_{2}\right)_{2}\left(o-\mathrm{C}_{20} \mathrm{H}_{11} \mathrm{~N}_{5}\right)\right]\left[\mathrm{PF}_{6}\right]_{2} \cdot 3\left(\mathrm{H}_{2} \mathrm{O}\right)$ : C 44.54, H: 3.08, N: 11.69; found C 44.68, H: 3.18, N: 11.68. MALDI-TOF MS (m/z): $[\mathrm{M}-\mathrm{H}]^{+}$Actual mass: 734.1389; Calculated mass: $734.1355 .{ }^{1} \mathrm{H}$ NMR $(400 \mathrm{MHz})$ in $\left(\mathrm{CD}_{3}\right)_{2} \mathrm{SO}$ ppm; $14.7(1 \mathrm{H}, \mathrm{s}, \mathrm{H} 16), 9.07(2 \mathrm{H}, \mathrm{d}, \mathrm{H} 11,17, J=8), 8.87$ (4H, m, H 1, 8, 20, 27), 8.23 (3H, d, H12, 7, 21), 8.1 (5H, m, H15, 2, 26, 9, 19), 8.03 (1H, t, H13), 7.96 (2H, m, H 10,18), 7.86 (3H, m, H14, 5, 23), 7.50 (4H, m, H 4, 24, 6, 22), 7.36 (2H, t, H 3, 25). ${ }^{13} \mathrm{C}$ NMR ppm; 156.72, 156.49, 151.51 (C 34, 61), 151.37 (C 31, 64), 150.17 (C 38, 57), 145.36, 137.95 (C 36, 59), 137.79 (C 29, 66), 135.30, 133.66 (C 48), 130.5 (C46), 129.43 (C47), 127.72 (C 39, 56), 127.0 (C 30, 65), $124.42 \& 124.32$ (C 28, 37, 58, 67), 118.5 (C49), 110.31 (C51).

\subsubsection{Synthesis of $\left[R u(p h e n){ }_{2} m-F P I P\right]^{2+}$}

The complex was synthesised as described for $\left[\mathrm{Ru}(\mathrm{phen})_{2} p-\mathrm{FPIP}\right]^{2+}$ with $m$-FPIP $(0.097 \mathrm{mg}, 0.3 \mathrm{mmol})$ replacing $p$-FPIP. Yield: $0.129 \mathrm{~g}$ (66\%). Elemental analysis (\%) Calculated for $\left[\mathrm{Ru}\left(\mathrm{C}_{12} \mathrm{H}_{8} \mathrm{~N}_{2}\right)_{2}(m-\right.$ $\left.\left.\mathrm{C}_{20} \mathrm{H}_{12} \mathrm{~N}_{4}\right)\right]\left[\mathrm{PF}_{6}\right]_{2} 3\left(\mathrm{H}_{2} \mathrm{O}\right): \mathrm{C} 46.78, \mathrm{H}: 3.03, \mathrm{~N}$ : 9.92; found C 46.52, $\mathrm{H}$ : 3.28, N: 9.71. ${ }^{1} \mathrm{H}$ NMR (400 MHz) in $\left(\mathrm{CD}_{3}\right)_{2} \mathrm{SO} \mathrm{ppm} ; 14.61(1 \mathrm{H}, \mathrm{s}, \mathrm{H} 17)$, 10.19 (1H, s, H15), 9.08 (2H, d, H11, 18, $J=8.4$ ), 8.84 (1H, s, H16), 8.78 (4H, d, H3, 6, 23, 26), 8.65(1H, s, H12, $J=8$ ), 8.41 (4H, s, H4, 5, 24, 25), 8.15 (3H, m, H14, 1, 8), 8.46 (2H, d, H 21, 28), 8.03 (2H, d, H 9, 20), 7.92(1H, t, H13), 7.80 (6H, m, H 2, 7, 22, 27, 10, 19). ${ }^{13} \mathrm{C}$ NMR ppm; 193.06 (C15), 152.80 (C29, 40), 152.62 (C61, 72), 150.39 (C41, 60), 147.19, 147.11, 145.54, 136.93 \& 136.79 (C31, 38, 63, 70),
132.04, 130.42(C43, 58), 128.04 (C34, 35, 66, 67), 126.28\& 126.01 (C54, 30, 39, 62, 71, 42, 59).

\subsubsection{Synthesis of $\left[R u(p h e n)_{2} p-C P I P\right]^{2+}$}

cis-[Ru(phen $\left.)_{2} \mathrm{Cl}_{2}\right] .2 \mathrm{H}_{2} \mathrm{O}(0.142 \mathrm{~g}, 0.25 \mathrm{mmol})$ and $p$-CPIP $(0.080 \mathrm{~g}$, $0.3 \mathrm{mmol})$ were dissolved in $50 \mathrm{~mL}$ ethanol: water $(1: 1 \mathrm{v} / \mathrm{v})$ and heated under reflux for $8 \mathrm{~h}$. Yield: $0.151 \mathrm{~g}(77 \%)$. Elemental analysis (\%) calculated for $\left[\mathrm{Ru}\left(\mathrm{C}_{12} \mathrm{H}_{8} \mathrm{~N}_{2}\right)_{2}\left(p-\mathrm{C}_{20} \mathrm{H}_{11} \mathrm{~N}_{5}\right)\right]\left[\mathrm{PF}_{6}\right]_{2} \cdot 1\left(\mathrm{H}_{2} \mathrm{O}\right)$ : C 48.45, $\mathrm{H}$ : 2.68, N: 11.68; found C 48.24, H: 2.44, N: 11.66. MALDI-TOF $(\mathrm{m} / \mathrm{z})$ : $[\mathrm{M}-\mathrm{H}]^{+}$Actual mass: Actual mass: 782.1353; Calculated mass: $782.1355{ }^{1} \mathrm{H}$ NMR $(400 \mathrm{MHz})$ in $\left(\mathrm{CD}_{3}\right)_{2} \mathrm{SO} \mathrm{ppm} ; 14.63(1 \mathrm{H}, \mathrm{s}, \mathrm{H} 16)$, 9.06 (2H, br s, H11, 17), 8.79 (4H, m, H3, 6, 22, 25), 8.48 (2H, d, H12, 15), 8.41(4H, s, H 4, 5, 23, 24), 8.16 (4H, d, H13, 14, 9,19), 8.08 (4H, m, H1, 8, 20, 27), 7.80 (6H, m, H, 2, 7, 21, 26, 10, 18). ${ }^{13} \mathrm{C}$ NMR ppm; $152.82 \& 152.63(\mathrm{C} 28,39,60,71), 150.75 \& 150.55$ (C40, 59), 147.18, 147.09, 145.74, 136.82(C30, 37, 62, 69), 133.36 \& 133.29 (49, 52), 130.42(C42, 57), 128.03 (33, 34, 65, 66), 127.02(C48, 53), 126.33\& 126.27(C41, 58, 29, 38,61, 70), 118.5 (C51), 112.27(C50).

\subsubsection{Synthesis of $\left[R u(p h e n)_{2} m-C P I P\right]^{2+}$}

The complex was synthesised as described for $\left[\mathrm{Ru}(\mathrm{phen})_{2} p-\mathrm{CPIP}\right]^{2+}$ with $m$-CPIP $(0.080 \mathrm{~g}, 0.3 \mathrm{mmol})$ replacing $p$-CPIP. Yield: $0.153 \mathrm{~g}$ (78\%). Elemental analysis (\%) calculated for $\left[\mathrm{Ru}\left(\mathrm{C}_{12} \mathrm{H}_{8} \mathrm{~N}_{2}\right)_{2}(m\right.$ $\left.\left.\mathrm{C}_{20} \mathrm{H}_{11} \mathrm{~N}_{5}\right)\right]\left[\mathrm{PF}_{6}\right]_{2} \cdot 3\left(\mathrm{H}_{2} \mathrm{O}\right): \mathrm{C} 46.90, \mathrm{H}: 2.95, \mathrm{~N}: 11.19$; found C $46.70, \mathrm{H}$ : 2.60, N: 10.96. MALDI-TOF $(\mathrm{m} / \mathrm{z})$ : $[\mathrm{M}-\mathrm{H}]^{+}$Actual mass: 782.1367 ; Calculated mass: $782.1355 .{ }^{1} \mathrm{H}$ NMR $(400 \mathrm{MHz})$ in $\left(\mathrm{CD}_{3}\right)_{2} \mathrm{SO} \mathrm{ppm} ; 14.3$ (1H, s, H16), 9.03 (2H, d, H11, 17, $J=8.4$ ), 8.79 (4H, d, H3, 6, 22, 25), 8.67 (1H, s, H15), 8.61 (1d, H12) 8.41 (4H, s, H 4,5, 23, 24), 8.15 (2H,d, H1, 8), 8.07 (5H, m, H14, 9, 19, 20, 27), 7.83 (7H, m, H13, 10, 18, 2, 7, 21, 26). ${ }^{13} \mathrm{C}$ NMR ppm; 152.81 (C28, 39), 152.62(C60, 71), 150.66 \& 150.39 (C40, 59), 147.17, 147.09, 145.69, 136.81 (C30, 37, 62, 69), 133.54(C50), 130.93 (C48), 130.56(C49), 130.42(C42, 57), 130.33, 129.03 (C53), 128.03 (C33, 34, 65, 66), 126.33(29, 38, 61, 70, 41, 58), 118.27 (C51), 112.37 (C52).

\subsubsection{Synthesis of $\left[R u(p h e n)_{2} \mathrm{O}-C P I P\right]^{2+}$}

The complex was synthesised as described for $\left[\mathrm{Ru}(\mathrm{phen})_{2} p-\mathrm{CPIP}\right]^{2+}$ with $o$-CPIP (0.080 g, $0.3 \mathrm{mmol}$ ) replacing $p$-CPIP. Yield: $0.133 \mathrm{~g}(68 \%)$. Elemental analysis (\%) calculated for $\left[\mathrm{Ru}\left(\mathrm{C}_{12} \mathrm{H}_{8} \mathrm{~N}_{2}\right)_{2}\left(o-\mathrm{C}_{20} \mathrm{H}_{11} \mathrm{~N}_{5}\right)\right]$ $\left[\mathrm{PF}_{6}\right]_{2} \cdot 2\left(\mathrm{H}_{2} \mathrm{O}\right): \mathrm{C} 47.66, \mathrm{H}: 2.82, \mathrm{~N}: 11.37$; found C 47.61, H: 2.42 , N: 11.03. MALDI-TOF $(\mathrm{m} / \mathrm{z})$ : $[\mathrm{M}-\mathrm{H}]^{+}$Actual mass: 782.1366; Calculated mass: $782.1355 .{ }^{1} \mathrm{H}$ NMR $(400 \mathrm{MHz})$ in $\left(\mathrm{CD}_{3}\right)_{2} \mathrm{SO} \mathrm{ppm} ; 14.63(1 \mathrm{H}, \mathrm{s}$, H16), 9.01 (2H, d, H11, 17), 8.79 (4H, d, H3, 6, 22, 25), 8.42 (4H, d, $\mathrm{H} 4,5,23,24), 8.26$ (1H, d, H12), 8.17 (3H, m, H13, 1, 8), $8.12(2 \mathrm{H}, \mathrm{dd}$, H, 20, 27), 8.05(3H, m, H14, 9, 19), 7.81 (7H, m, H 15, 2,7, 21, 26, 10, 18). ${ }^{13} \mathrm{C}$ NMR ppm; 152.85 (C28, 39), 152.63 (C60, 71), 150.63 (C40, 59), 149.69, 147.18, 147.10, 145.77, 136.77 (C30, 37, 61, 68), 135.29 (C49), 133.65 (C50), 132.02, 130.62 (C52), 130.42 (C42, 57), 130.35, 129.41 (C48), 128.02 (C33, 34, 64, 65), 126.32 \& 126.26 (C29, 38, 61, 70, 41, 58), 118.07 (C51), 110.27 (C53).

\subsection{DNA binding studies}

A number of different instrumental techniques were utilised to study the interactions between DNA and the synthesised Ru(II) complexes. The methodology of selective discrimination allowed the elimination of the least favourable complexes after each technique. This allowed emphasis to be placed on the complexes showing the most promising results. The various techniques that were used to study the binding of the complexes with DNA included electronic spectroscopy (UV/Vis and fluorescent), circular dichroism (CD), and thermal denaturation (TD) [30,31].

The following study was carried out with deoxyribonucleic acid (DNA) sodium salt from calf thymus (CT) (Sigma Aldrich) prepared in freshly prepared Sodium Cacodylate/ $\mathrm{Na}_{2}$ EDTA buffer $(\mathrm{pH}=7)$. 


\subsubsection{Buffer}

$10 \mathrm{mM} \quad(0.2510 \mathrm{~g}) \quad$ Sodium cacodylate trihydrate [Na $\left.\left(\mathrm{CH}_{3}\right)_{2} \mathrm{AsO}_{2} \cdot 3 \mathrm{H}_{2} \mathrm{O}\right]$ and $0.1 \mathrm{mM}(0.0037 \mathrm{~g}) \mathrm{Na}_{2}$ EDTA solution was prepared with $90 \mathrm{~mL}$ of pure water in a beaker and brought to a $\mathrm{pH}$ of 7.0 by the drop-wise addition of $1 \mathrm{M} \mathrm{HCl}$. The solution was transferred into a $100 \mathrm{~mL}$ volumetric flask and made up to the mark with deionised water.

\subsubsection{Preparation of the DNA solution}

$6.4 \mathrm{mg}$ of CT-DNA was placed into an ependorf tube and $1 \mathrm{~mL}$ of the cacodylate/EDTA buffer ( $\mathrm{pH} 7$ ) was added. The ependorf was placed in a beaker of ice water and sonicated (4/5 times for $3 \mathrm{~s}$ intervals). The DNA solution was syringed out from the ependorf, and filtered with a $45 \mu \mathrm{L}$ membrane (Whatman) into a fresh ependorf tube.

\subsubsection{UV/Vis DNA titration}

The DNA solution was checked for homogeneity by the addition of specific amounts of calf thymu-DNA $(1-10 \mu \mathrm{L})$ into $2 \mathrm{~mL}$ of the sodium cacodylate/EDTA buffer. The DNA solutions were quantified spectrophotometrically using the Beer lambert law $\left(\varepsilon_{260}=6600 \mathrm{M}^{-1} \mathrm{~cm}^{-1}\right)$. A working standard from the stock DNA was prepared of $5 \mathrm{mM}$, of which set aliquots of DNA was added to the ruthenium samples. The purity of the DNA was checked by monitoring the value of $A_{260} / A_{280}$. The ratio was in excess of 1.80 for all samples used in the experiments so that the contents of residual proteins should be small. [26].

\subsubsection{Determining the complex/DNA binding constant $\left(K_{b}\right)$}

The initial complex-DNA interaction study was carried out by UV/ Visible absorption spectroscopy. Monitoring of spectral changes in the absorption profile of the complex or the DNA molecules can allow the calculation of an equilibrium binding constant $\left(\mathrm{K}_{\mathrm{b}}\right)$ and the site binding size (s) [25]. The equilibrium binding titration technique was used where the complex solution of a fixed concentration $(15 \mu \mathrm{M})$ is transferred into a thermostated cuvette containing $2000 \mu \mathrm{L}$ of buffer and the progressive absorbance changes were monitored after each addition of serial aliquots from a stock DNA $(10 \mathrm{mM})$ solution. Additions of DNA into the complex solution and the resultant reduction in absorbance (hypochromic shift) and a bathochromic shift in the $\lambda_{\max }$ were recorded. Aliquots of DNA were added until there was a no further reduction in the absorption intensity. Each cuvette was maintained at a constant temperature of $25^{\circ} \mathrm{C}$ by the peltier temperature programmer (PerkinElmer PTP-1 Peltier system). Between each sample addition, the cuvette was inverted several times for even distribution and to allow for thermal equilibrium for approximately $10 \mathrm{~min}$ prior to measurement. The absorbance (A) measured at any wavelength reflects both the free and DNA-bound complex species as shown in Eq. (1.1) [32].

$A=A_{f}+A_{b}=\varepsilon_{f} * C_{f}+\varepsilon_{b} * C_{b}$

where $\mathrm{C}$ is the fixed complex concentration $\left(\mathrm{C}_{\mathrm{f}}\right.$, free and $\mathrm{C}_{\mathrm{b}}$, bound $)$ and $\varepsilon_{\mathrm{f}}$ and $\varepsilon_{\mathrm{b}}$ represent the respective extinction coefficients. The intrinsic DNA binding constant $\mathrm{K}_{\mathrm{b}}$ were obtained from monitoring the change in the absorbance of the MLCT $\lambda_{\max }$ according to the following Eqs. (1.2) and (1.3) [33].

$\left(\varepsilon_{a}-\varepsilon_{f}\right) /\left(\varepsilon_{b}-\varepsilon_{f}\right)=\left(b-\left(b^{2}-2 K_{b}^{2} C_{t}[D N A] / s\right)^{1 / 2}\right) / 2 K_{b} C_{t}$

$\mathbf{b}=\mathbf{1}+\mathrm{K}_{\mathrm{b}} \mathrm{C}_{\mathrm{t}}+\mathrm{K}_{\mathrm{b}}[\mathrm{DNA}] / 2 \mathrm{~s}$

where [DNA] is the concentration of DNA in nucleotides, $\varepsilon_{\mathrm{a}}$ is the extinction coefficient $\left(\mathrm{A}_{\mathrm{abs}} /[\mathrm{M}]\right.$ ) observed for the MLCT absorption band at a given DNA concentration, $\varepsilon_{\mathrm{f}}$ and $\varepsilon_{\mathrm{b}}$ are the extinction coefficients for the free Ru(II) complex and the extinction coefficient for the $\mathrm{Ru}(\mathrm{II})$ complex in the fully bound form, respectively. $\mathrm{K}_{\mathrm{b}}$ is the equilibrium binding constant in $\mathrm{M}^{-1}, \mathrm{C}_{\mathrm{t}}$ is the total $\mathrm{Ru}(\mathrm{II})$ complex concentration and $\mathrm{s}$ is the binding site size [32].

An inorganic complex binding to DNA through intercalation usually results in hypochromism and bathochromism shifts, due to the intercalation mode involving a strong $\pi-\pi$ stacking interaction between an aromatic chromophore and the base pairs of DNA [33]. The extent of the hypochromism in the UV/Vis band is consistent with the strength of the intercalative interaction. Percentage hypochromism $(\mathrm{H} \%)$ is defined by Eq. (1.4) [33].

$\mathbf{H} \%=\mathbf{1 0 0} \% \times \frac{(\text { Afree-Abound })}{\text { Afree }}$

The interaction of the complexes with calf thymus DNA (CT-DNA) began with electronic absorption titrations which, allows determination of the binding affinity and percentage hypochromism.

The Ru(II) complexes were further explored by thermal denaturation and circular dichroism experimentation. Thermal behaviours of DNA in the presence of complexes can give insight into DNA conformational changes when the temperature is raised and offers information about the interaction strength of the complexes with DNA. According to the literature, the intercalation of natural or synthesised organic and metallointercalators generally result in a considerable increase in melting temperature $\left(\mathrm{T}_{\mathrm{m}}\right)$ [34].

\subsubsection{Circular dichroism}

DNA:complex samples of different ratios; 160:1, 80:1, 40:1, 24:1, $20: 1,16: 1,12: 1,6: 1$ were prepared. A set concentration of $150 \mu \mathrm{M}$ of DNA was used. The volume is pipetted into the sample vial containing $2 \mathrm{~mL}$ of the buffer. The initial Ru complex concentration was $25 \mu \mathrm{M}$, upon which varying concentrations were titrated into the DNA buffered solutions and incubated overnight at $37^{\circ} \mathrm{C}$. Circular dichroism (CD) is the difference in absorption of left $\left(\mathrm{A}_{\ell}\right)$ and right circularly polarized light $\left(\mathrm{A}_{r}\right)$ as shown in Eq. (1.5) [35]:

$\mathrm{CD}=\mathrm{A}_{\ell}-\mathrm{A}_{r}$

\subsubsection{Thermal denaturation}

The melting temperature $\left(\mathrm{T}_{\mathrm{m}}\right)$ of the DNA solution, which is defined as the temperature where half of the total base pairs are unbound, is usually measured to study the interaction of transition metal complexes with nucleic acid. Generally, the melting temperature of DNA increases when metal complexes bind to DNA by intercalation, as intercalation of the complexes between DNA base pairs causes stabilisation of base pair stacking and hence raises the melting temperature of double-stranded DNA [32]. The thermal denaturation experiment was performed on the $\mathrm{UV} / \mathrm{Vis}$ spectrophotometer by recording the absorbance at $260 \mathrm{~nm}$ as a function of temperature. The DNA to complex ratio for all of the samples was set at 10:1; DNA $(50 \mu \mathrm{M})$ and complex solution $(5 \mu \mathrm{M})$. The temperature was increased at a thermal gradient of $0.4{ }^{\circ} \mathrm{C} / \mathrm{min}$ and readings were taken every $2{ }^{\circ} \mathrm{C}$ within the range of $40-90^{\circ} \mathrm{C}$. Experiments were run in triplicate and averages obtained.

The melting of DNA can be monitored very efficiently using UV/Vis absorption spectroscopy. Because of their aromatic structure, each of the four DNA bases has a characteristic absorption spectrum, the sum of the absorption spectra of the four aromatic bases has $\left(\lambda_{\max }=260 \mathrm{~nm}\right)$ [32]. When DNA melts and the two strands separate, the electronic interactions between the bases are modified and the entire absorption spectrum increases in intensity [32]. This increase in absorption due to melting is typically between 30 and $40 \%$ [32].

\subsubsection{Cell culture}

The A375 (ATCC ${ }^{\circledast}$ CRL-1619), HeLa (ATCC ${ }^{\circledR}$ CCL-2), A549 (ATCC $^{\circledR}$ CCL-185), BEAS-2B (ATCC ${ }^{\circledR}$ CRL-9609) and MCF7 (ATCC ${ }^{\circledR}$ HTB22) cell lines were all purchased from the ATTC (Manassas, VA, USA). All tested cell lines were cultured in RPMI-1640 medium supplemented with $10 \%$ FBS (foetal bovine serum), $45 \mathrm{IU} / \mathrm{mL}$ penicillin, $45 \mathrm{IU} / \mathrm{mL}$ streptomycin and L-glutamine (1\%) (HeLa media) at $37^{\circ} \mathrm{C}$ in a humidified incubator at $5 \% \mathrm{CO}_{2}$. 


\subsubsection{In vitro cytotoxicity}

A cytotoxicity assessment for the complexes and isolated ligands were conducted with the MTT assay. All complexes were tested against the cells over the concentration $250-0.9 \mu \mathrm{M}$, whereas the ligand were tested over a broader range of $500-1.9 \mu \mathrm{M}$, to ensure an appropriate dose response in the cytotoxic profile as to calculate IC50 values as a result of the exposures. In all viability experiments a $10 \%$ dimethyl sulfoxide (DMSO) was also used as a positive kill control to validate assay function in all exposures. For testing, stock concentrations of all complexes and ligands were prepared using fully supplemented media, which were diluted further with fully supplemented media by serial dilution for definitive concentration range testing. For the MTT assay cells were seeded in 96 well microtitre plates (Nunc, Denmark) at a density of $1 \times 10^{5}$ cells $/ \mathrm{mL}$ for $24 \mathrm{~h}$ exposure and $3 \times 10^{4}$ cells $/ \mathrm{mL}$ for $96 \mathrm{~h}$ exposures respectively, in $100 \mu \mathrm{L}$ of medium containing $10 \%$ FBS. Three independent experiments were conducted and eight replicate wells were employed per concentration per plate. Following $24 \mathrm{~h}$ of cell attachment, plates were washed with $100 \mu \mathrm{L} /$ well phosphate buffered saline (PBS), further treated with $100 \mu \mathrm{L} /$ well of the respective complex under test and incubated for the required time point. After exposure, the medium for the controls or test exposures were removed, the cells were washed with PBS. Stock solution of MTT was prepared $(5 \mathrm{mg} / 5 \mathrm{~mL}$ of MTT in PBS) and $100 \mu \mathrm{L}$ of freshly prepared MTT in media (1 mL/ $10 \mathrm{~mL}$ of MTT stock in media (without FBS or supplements) were added to each well. After $3 \mathrm{~h}$ incubation, the medium was discarded and the cells were rinsed with PBS and $100 \mu \mathrm{L}$ of MTT fixative solution (DMSO) were added to each well and the plates were shaken at $240 \mathrm{rpm}$ for $10 \mathrm{~min}$. The absorbance was then measured at $595 \mathrm{~nm}$ in a SpectraMax M3 Multi-Mode Microplate Reader (Molecular Devices, USA).

\subsubsection{Statistical analysis}

In all in vitro testing at least three independent experiments with eight replicate wells per exposure concentration were conducted in triplicate for all experiments. Test results for each assay were expressed as percentage of the unexposed control \pm standard deviation (SD). Control values were set at $100 \%$. Statistical analysis was performed on the raw data using GraphPad Prism version 7. Data were analysed by Two-way analysis of variance (ANOVA)-Tukeys multiple comparison tests to detect significance in effects between exposure groups and Sidak multiple comparison tests to detect for significance in effects within the groups. Statistically significant differences in tests were indicated for $p$ value $<0.05$. Cytotoxicity data for the MTT assay was fitted to a sigmoidal curve and four parameter logistic model to calculate the $\mathrm{IC}_{50}$ values and they were reported as $\pm 95 \%$ confidence interval. All quoted $\mathrm{IC}_{50}$ values were estimated using GraphPad Prism 7.0.

\section{Results and discussion}

\subsection{Electronic absorption titration}

Electronic absorption spectroscopy is a reliable method to investigate the interactions of macromolecules with DNA. In this study $\mathrm{UV} / \mathrm{Vis}$ absorption titrations were employed to investigate the propensity of a library of ruthenium polypyridyl complexes to bind to calf thymus DNA. The binding strength, site size and mode of action were seen to differ with variation of both the co-ordinated and auxiliary ligands attached to the metal centre. The auxiliary ligands exhibit significant absorption features in the DNA absorption region and as such it was more prudent to monitor the absorption peak of the ruthenium complex for evidence of interaction. The aim of this biological study is to evaluate the potential of a series of Ru based complexes to intercalate/interact with DNA. As such it is critical to first evaluate the effect of the isolated coordinated ligands and their affinity to DNA. This will allow the elucidation of the impact of the metal centre in relation to the potential of DNA binding.

Fig. 2 shows the effect of varying concentration of CT-DNA (0.01-0.8 mM) on the electronic absorption spectra of $27.5 \mu \mathrm{M}$ of the isolated NPIP (left) and FPIP (right) and The intense broad absorption band of these ligands occur in the UV region $(380 \mathrm{~nm})$ due to a strong intra-ligand transition between $\pi$ and $\pi^{*}$ energy levels of the polypyridyl ligands aromatic system. The graphs below show no spectral shifting and no isobestic point is present. This suggests a lack of interaction between the ligand and the DNA.

\subsection{Fluorescence DNA titration}

Fluorescence spectroscopy another technique commonly used to study interactions between small ligand molecules and DNA. The advantages of molecular fluorescence over other techniques are its high sensitivity, large linear concentration range and selectivity. The series of polypyridyl ligands (FPIP, BPIP, CPIP and NPIP) proved to be intensely fluorescent.

In the case of fluorescence, a significant increase in the fluorescence emission is normally observed for intercalative modes of interaction while a decrease in the fluorescence intensity is observed for groove binding agents, electrostatic, hydrogen binding or hydrophobic interactions [32]. In Fig. 3 a slight reduction in fluorescence intensity is observed with the increased DNA concentration however this is not a significant observation and can be attributed to a dilution effect due to the incrementally added DNA volume. This is further evidence that the free ligands do not strongly interact with DNA. The experimental data from the aforementioned UV/Vis and fluorescence binding titrations is reinforced by circular dichroism measurements at different complex:DNA ratios for the ligands. $\mathrm{CD}$ was performed on the ligands as one

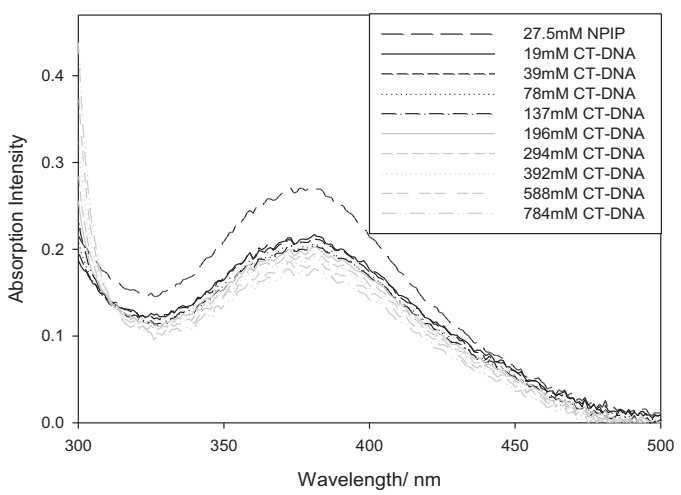

Fig. 2. The effect of varying concentration of CT-DNA (0.01-0.25 mM) on the electronic absorption spectra of $25 \mu \mathrm{M}$ of NPIP (left) and FPIP (right). 

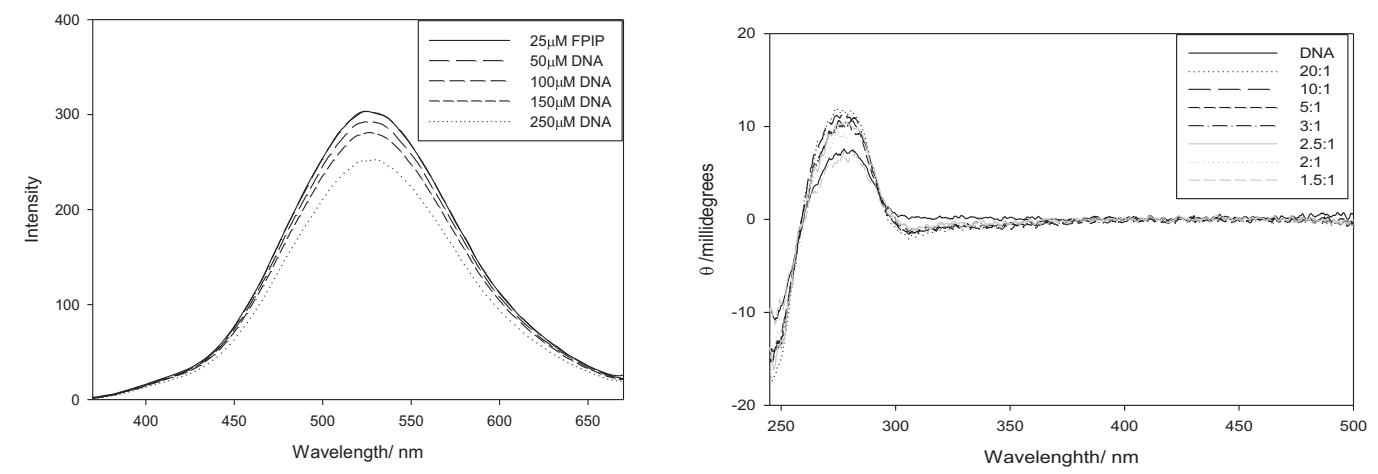

Fig. 3. Emission (left) and Circular Dichroism (right) spectrum of FPIP in buffer at $25{ }^{\circ} \mathrm{C}$ in the presence of increasing amounts of CT-DNA.

final test to confirm the lack of interaction. Fig. 3 shows the CD spectrum of the isolated FPIP ligand and it is evident from the spectrum that no new features are introduced with the addition of the DNA; again the peak reduction can be attributed to a dilution effect.

\subsection{Complex DNA titration}

The isolated main ligands show a negligible affinity for DNA, the systematic study is to evaluate the ruthenium complexes in the presence of CT-DNA. The $\left[\mathrm{Ru}(\mathrm{phen})_{2} \mathrm{~L}\right]^{2+}$ complexes, where $\mathrm{L}=p$-FPIP, $p$-CPIP, $p$-NPIP and $p$-BPIP show absorption maxima at 456, 458, 463 and $453 \mathrm{~nm}$ but upon addition of DNA exhibit UV/Vis absorption maxima at $460,460,461$ and $459 \mathrm{~nm}$ respectively. The electronic absorption spectra of the $\left[\mathrm{Ru}(\mathrm{bpy})_{2} \mathrm{~L}\right]^{2+}$, complexes, where $\mathrm{L}=p$-FPIP, $p$-CPIP, $p$ NPIP and $p$-BPIP show similar characteristics and shift to $460,462,457$ and $461 \mathrm{~nm}$ respectively when bound to DNA.

The intercalative binding with DNA results in hypochromic and bathochromic shifts and this is evident in the absorption spectrum of the novel $\left[\mathrm{Ru}(\text { phen })_{2} p \text {-CPIP }\right]^{2+}$ complex, Fig. 4 . The reduction and red shift in absorbance is typical of the intercalative mode involving a stacking interaction between the ligand chromophore and the base pairs of DNA, the extent of the hypochromism is usually consistent with the strength of intercalative interaction [30]. The initial hypochromic and slight bathochromic shifts can best be described by the lowering in MLCT and $\pi$ and $\pi^{*}$ transition energy of the metal and ligand in Ru(II) complexes due to their ordered stacking between the DNA base pairs after intercalation [30]. After binding to the DNA, the $\pi$ orbital of the binding ligand is free to couple with $\pi$ orbital of the base pairs in the DNA. The coupling $\pi$ orbital was partially filled by electrons, thus decreasing the transition probabilities, and hence resulting in the hypochromicity. Thus, the energy level of the $\pi-\pi^{*}$ transition decreases, and results in a red shift [30].

The above shifts in absorbance are accompanied with the appearance of two isobestic points near $\sim 275$ and $\sim 475 \mathrm{~nm}$. This phenomenon was observed for all of the complexes. All of the [Ru (phen) $\left.)_{2} \mathrm{~L}\right]^{2+}$ and $\left[\mathrm{Ru}(\mathrm{bpy})_{2} \mathrm{~L}\right]^{2+}$ when titrated with CT-DNA produced hypochromic and bathochromic shifts. These shifts are due to the intercalation of the complex, involving a strong $\pi-\pi$ stacking interaction between an aromatic chromophore and the base pairs of DNA. The extent of the hypochromism in the UV/Vis band is analogous with the strength of the binding interaction. On average the ruthenium complexes consisting of the phenanthroline auxiliary ligands produced the highest percentage hypochromic shift, followed by the bipyridine complexes. It has been well documented that the phen and bpy based complexes show a large hypochromic shift in the spectral intensity. The values found in this study are consistent with reported values for the percentage hypochromic shift e.g. $\left[\mathrm{Ru}(\mathrm{phen})_{2} \mathrm{dppz}\right]^{2+}=18.9 \%$ and $\left[\mathrm{Ru}(\mathrm{bpy})_{2} \text { pip }\right]^{2+}=21.9 \%$ [36-38]. The largest percentage hypochromic shifts were produced by the NPIP terminated complexes, with $\left[\mathrm{Ru}(\mathrm{phen})_{2} \mathrm{NPIP}\right]^{2+}$ and $\left[\mathrm{Ru}(\mathrm{bpy})_{2} \mathrm{NPIP}\right]^{2+}$ measuring $27.4 \%$ and $25.6 \%$ respectively which directly correlates with the higher calculated binding constants in Table 2. Considerable large hypochromic shift was seen for all of the series of $\left[\mathrm{Ru}(\mathrm{phen})_{2} \mathrm{~L}\right]^{2+}$ and $\left[\mathrm{Ru}(\mathrm{bpy})_{2} \mathrm{~L}\right]^{2+}$ complexes. The CPIP, FPIP and BPIP complexes all display a reduction in the MLCT absorption band of 16.6, 19.1 and $18.1 \%$ respectively for the $\left[\mathrm{Ru}(\mathrm{phen})_{2} \mathrm{~L}\right]^{2+}$ and $19.1,18.2$ and $17.6 \%$ respectively for the [Ru $\left.(\text { bpy })_{2} \mathrm{~L}\right]^{2+}$. When examining the hypochromic shifts as a function of the positional changes on the main polypyridyl ligand (para, meta and ortho), it is worth noting that it is the ortho positioned nitrile groups (CN) producing the least \% hypochromic shift, alongside their slightly lower binding constants $\left(\mathrm{K}_{\mathrm{b}}\right)$; $\left(\left[\mathrm{Ru}(\mathrm{phen})_{2} \mathrm{O}-\mathrm{CPIP}\right]^{2+}=11.5 \%\right.$ and $[\mathrm{Ru}$ (bpy) $\left.{ }_{2} \mathrm{O}-\mathrm{CPIP}\right]^{2+}=5.6 \%$ ). While the para and meta positioned nitrile complexes produce consistently higher hypochromic shifts of $\sim 18 \%$ coinciding with their higher $\mathrm{K}_{\mathrm{b}}$ binding constants. This suggests that the para and meta CPIP complexes are more strongly binding to DNA base pairs than the ortho analogues. This result can be expected, on the basis
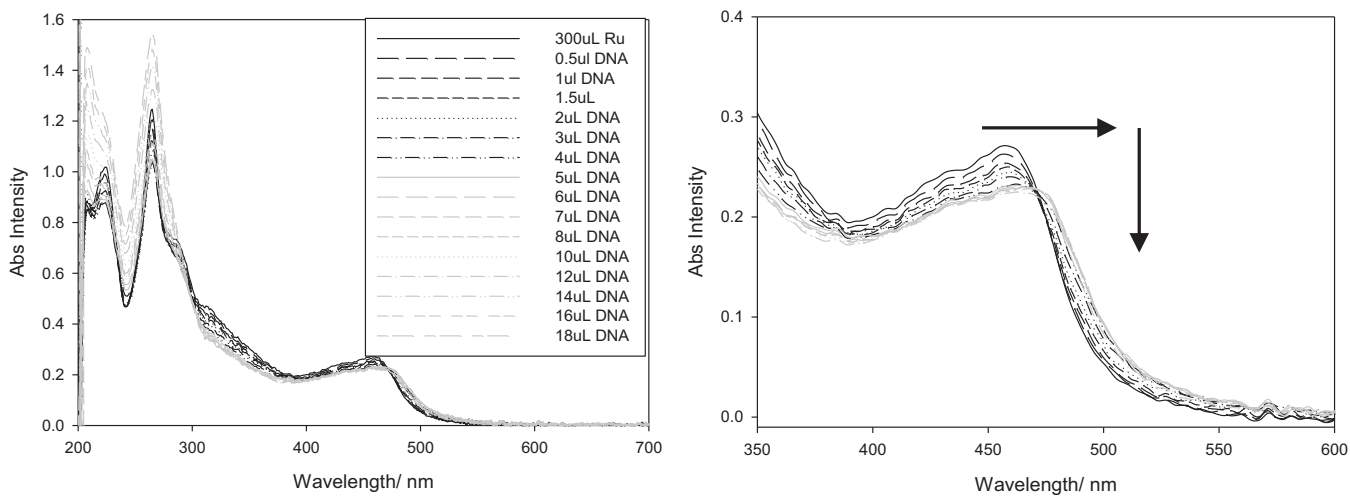

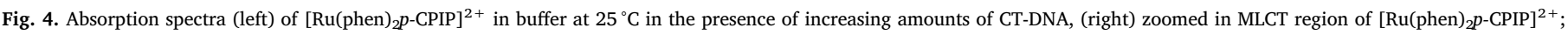
arrow indicates the change in absorbance upon increasing DNA concentration. 
Table 2

DNA binding site size (s), binding constants $\left(\mathrm{K}_{\mathrm{b}}\right)$ and thermal denaturation melting point $\left(\mathrm{T}_{\mathrm{m}}\right)$ of the $\mathrm{Ru}(\mathrm{II})$ complexes.

\begin{tabular}{|c|c|c|c|c|}
\hline Complexes & $\begin{array}{l}\text { Binding Site } \\
\text { Size (s) }\end{array}$ & $\begin{array}{l}\text { Binding Constant } \\
\left(\mathrm{k}_{\mathrm{b}}\right) \mathrm{M}^{-1}\end{array}$ & $\mathrm{~T}_{\mathrm{m}}\left({ }^{\circ} \mathrm{C}\right)$ & $\Delta \mathrm{T}_{\mathrm{m}}\left({ }^{\circ} \mathrm{C}\right)$ \\
\hline $\begin{array}{c}{\left[\mathrm{Ru}(\mathrm{phen})_{2} p-\right.} \\
\mathrm{CPIP}^{2+}\end{array}$ & 0.8 & $0.9 \times 10^{6}$ & 80 & 15.4 \\
\hline $\begin{array}{c}{\left[\mathrm{Ru}(\mathrm{phen})_{2} m-\right.} \\
\mathrm{CPIP}^{2+}\end{array}$ & 0.8 & $0.8 \times 10^{6}$ & 79.7 & 15.1 \\
\hline $\begin{array}{c}{\left[\mathrm{Ru}(\mathrm{phen})_{2} \mathrm{O}-\right.} \\
\mathrm{CPIP}^{2+}\end{array}$ & 0.8 & $0.4 \times 10^{6}$ & 77.3 & 12.7 \\
\hline $\begin{array}{c}{\left[\mathrm{Ru}(\mathrm{phen})_{2} p-\right.} \\
\mathrm{BPIP}]^{2+}\end{array}$ & 1.1 & $0.9 \times 10^{6}$ & 71.2 & 6.6 \\
\hline $\begin{array}{c}{\left[\mathrm{Ru}(\mathrm{phen})_{2} p-\right.} \\
\mathrm{FPIP}^{2+}\end{array}$ & 0.6 & $1 \times 10^{6}$ & 79.8 & 14.6 \\
\hline $\begin{array}{c}{\left[\mathrm{Ru}(\mathrm{phen})_{2} p-\right.} \\
\mathrm{NPIP}^{2+}\end{array}$ & 0.7 & $5 \times 10^{6}$ & 72.4 & 7.8 \\
\hline$\left[\mathrm{Ru}(\mathrm{bpy})_{2} p-\mathrm{CPIP}\right]^{2+}$ & 0.6 & $0.7 \times 10^{6}$ & 75.2 & 10.6 \\
\hline $\begin{array}{l}{\left[\mathrm{Ru}(\mathrm{bpy})_{2} m-\right.} \\
\left.\mathrm{CPIP}^{m-}\right]^{2+}\end{array}$ & 0.8 & $0.9 \times 10^{6}$ & 72.9 & 8.3 \\
\hline$\left[\mathrm{Ru}(\mathrm{bpy})_{2} \mathrm{o}-\mathrm{CPIP}\right]^{2+}$ & 0.9 & $0.7 \times 10^{6}$ & 69.9 & 5.3 \\
\hline$\left[\mathrm{Ru}(\mathrm{bpy})_{2} p-\mathrm{BPIP}\right]^{2+}$ & 0.2 & $0.8 \times 10^{6}$ & 72.4 & 7.8 \\
\hline$\left[\mathrm{Ru}(\mathrm{bpy})_{2} p \text {-FPIP }\right]^{2+}$ & 0.5 & $0.3 \times 10^{6}$ & 76.5 & 11.9 \\
\hline $\begin{array}{l}{\left[\mathrm{Ru}(\mathrm{bpy})_{2} p-\right.} \\
\mathrm{NPIP}]^{2+}\end{array}$ & 0.5 & $1 \times 10^{6}$ & 73.2 & 8.6 \\
\hline$\left[\mathrm{Ru}(\mathrm{bpy})_{3}\right]^{2+}$ & 0.1 & $9 \times 10^{4}$ & - & - \\
\hline Actinomycin D & 8 & $8 \times 10^{6}$ & - & - \\
\hline CT-DNA & - & - & 64.6 & - \\
\hline
\end{tabular}

that the para and meta substituted ligands possess a greater planar area and an extended $\pi$ system, hence higher hydrophobicity than that of the ortho substituted ligand, which would lead to $p$-CPIP and $m$-CPIP penetrating more deeply into, and stacking more strongly to CT-DNA [39]. A complex binding to DNA through intercalation usually results in hypochromism and bathchromism, due to the intercalation mode involving a strong $\pi-\pi$ stacking interaction between an aromatic chromophore and the base pairs of DNA. It seems to be generally accepted that the extent of the hypochromism in the UV/Visible region is consistent with the strength of the intercalative interaction [33].

The intrinsic binding constant, $\mathrm{K}_{\mathrm{b}}$ for the complexes $\left[\mathrm{Ru}(\mathrm{bpy})_{2} p\right.$ NPIP $]^{2+}$ and $\left[R u(p h e n)_{2} o-C P I P\right]^{2+}$ were found to be $1 \times 10^{6} \mathrm{M}^{-1}$ and $0.4 \times 10^{6} \mathrm{M}^{-1}$ respectively. The calculated binding constants are all within the range of $0.2-5 \times 10^{6} \mathrm{M}^{-1}$ up to the order of $10^{7} \mathrm{M}^{-1}$, which coincides with what has been reported for classical intercalators and metallointercalators [37,38].

The DNA binding affinity of complex $\left[\mathrm{Ru}(\mathrm{phen})_{2} \mathrm{NPIP}\right]^{2+}$ $\left(\mathrm{K}_{\mathrm{b}}=5 \times 10^{6} \mathrm{M}^{-1}\right)$ is remarkably greater than that of the bipyridine counterpart with $\mathrm{a} \mathrm{K}_{\mathrm{b}}=1 \times 10^{6} \mathrm{M}^{-1}$. Progression to the CPIP series also follows the same pattern of $\left[\mathrm{Ru}(\mathrm{phen})_{2} \mathrm{CPIP}\right]^{2+}$ yielding a binding constant of $\mathrm{K}_{\mathrm{b}}=0.9 \times 10^{6} \mathrm{M}^{-1}$, the bipyridine analogue binding constant being smaller at $0.7 \times 10^{6} \mathrm{M}^{-1}$. The $\left[\mathrm{Ru}(\text { phen })_{2} \mathrm{FPIP}\right]^{2+}$ complex follows this same pattern yielding a binding constant of $\mathrm{K}_{\mathrm{b}}=1 \times 10^{6} \mathrm{M}^{-1}$, with the bipyridine analogue binding constant being smaller $\left(\mathrm{K}_{\mathrm{b}}=0.3 \times 10^{6} \mathrm{M}^{-1}\right)$.

As both $\left[\mathrm{Ru}(\text { phen })_{2} \mathrm{~L}\right]^{2+}$ and $\left[\mathrm{Ru}(\mathrm{bpy})_{2} \mathrm{~L}\right]^{2+}$ analogues of the complexes were studied by UV/Vis DNA titrations the effect of the bidentate auxiliary ligands (bpy and phen) on the binding affinity can be observed. The difference in the binding constants indicates that the phen auxiliary ligand enhances the DNA-binding affinity compared with the bpy auxiliary ligand, since two of the complexes have the same intercalative ligands.

Shi et al. synthesised the Ru(II) complexes with their main polypyridyl ligand (L) the NPIP ligand structure synthesised in this study, (where L is $o$-NPIP (1), $m$-NPIP (2) and $p$-NPIP (3)) containing $\mathrm{NO}_{2}$ at different positions on the phenyl ring with the bpy auxiliary ligand [35]. Their para positioned $\mathrm{NO}_{2}$ complexes were isolated for the stereoisomers which were found to produce binding constants of $\mathrm{K}_{\mathrm{b}}$ $0.82 \times 10^{6} \mathrm{M}^{-1}$ for the $\Delta$ isomer and $0.73 \times 10^{6} \mathrm{M}^{-1}$ for the $\Lambda$ isomer

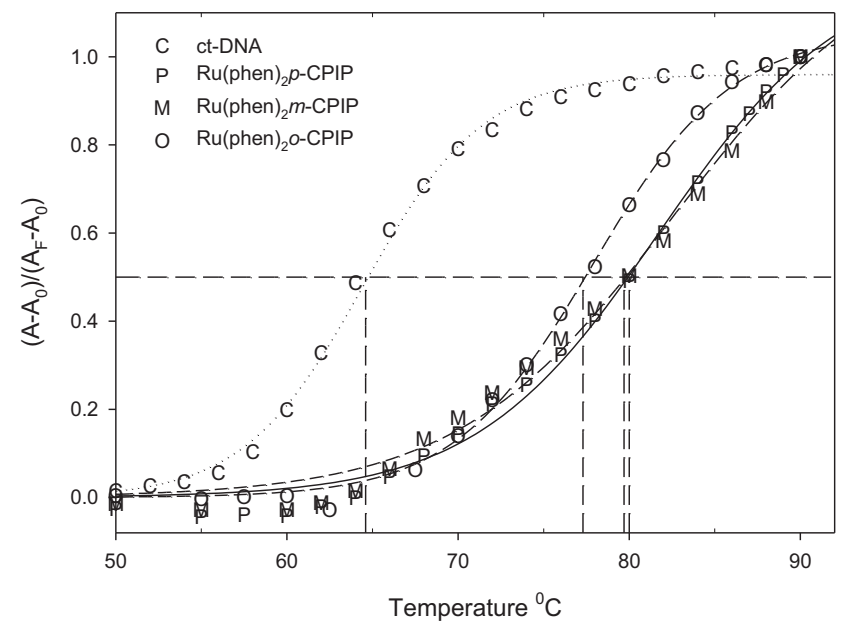

Fig. 5. Melting temperature curves for CT-DNA in the absence (C) and presence of the following complexes, $\left[\mathrm{Ru}(\mathrm{phen})_{2} p \text {-CPIP }\right]^{2+}(\mathrm{P}),\left[\mathrm{Ru}(\mathrm{phen})_{2} m-\mathrm{CPIP}\right]^{2+}(\mathrm{M})$ and $[\mathrm{Ru}$ (phen) $)_{2} o$-CPIP $]^{2+}(\mathrm{O})$. [DNA $]=50 \mu \mathrm{M},[\mathrm{Ru}]=5 \mu \mathrm{M},(10: 1$ ratio).

with large \% hypochromic shifts of 28 and $26 \%$ respectively giving similar experimental binding constants yielded by the [Ru (bpy) $\left.{ }_{2} p-\mathrm{NPIP}\right]^{2+}$ synthesised in this study of $1 \times 10^{6} \mathrm{M}^{-1}$ [40].

Table 2 depicts the interaction of $[\mathrm{Ru}(\mathrm{phen}) x \text {-CPIP }]^{2+}$ and CT-DNA with a systematically varied positional group on the CPIP polypyridyl ligand; where $x$ is a para, meta or ortho position. When examining the ruthenium (II) complexes, via regioisomers effect, a noticeable difference on the DNA binding constants can be observed. Three novel phenanthroline based regioisomers were chosen; $\left[\mathrm{Ru}(\mathrm{phen})_{2} p \text {-CPIP }\right]^{2+}$, $\left[\mathrm{Ru}(\mathrm{phen})_{2} m \text {-CPIP }\right]^{2+}$ and $\left[\mathrm{Ru}(\mathrm{phen})_{2} \mathrm{O}-\mathrm{CPIP}\right]^{2+}$ to study their interaction and stabilisation effect that they could produce on CT-DNA. The melting temperature $\left(\mathrm{T}_{\mathrm{m}}\right)$ values of each of these complexes are shown in Table 2, relative to CT-DNA.

Fig. 5 is a plot of all the regioisomers relative to CT-DNA. When examining the data from the regioisomer viewpoint the para and meta and ortho substituted nitrile groups all followed the same trend of; [Ru (phen $)_{2} p$-CPIP $]^{2+}\left(80^{\circ} \mathrm{C}\right)>\left[\mathrm{Ru}(\text { phen })_{2} m \text {-CPIP }\right]^{2+}\left(79.7^{\circ} \mathrm{C}\right)>[\mathrm{Ru}$ (phen) $)_{2} \mathrm{O}$-CPIP] ${ }^{2+}\left(77.3^{\circ} \mathrm{C}\right)$. Experiments were run in triplicate and averages allowed this figure to be obtained. This trend is also evident in the bipyridine complexes: $\left[\mathrm{Ru}(\mathrm{bpy})_{2} p \text {-CPIP }\right]^{2+}\left(75.2^{\circ} \mathrm{C}\right)>[\mathrm{Ru}$ (bpy $)_{2} \mathrm{~m}$-CPIP $]^{2+}\left(72.9^{\circ} \mathrm{C}\right)>\left[\mathrm{Ru}(\mathrm{bpy})_{2} \mathrm{O}-\mathrm{CPIP}\right]^{2+}\left(69.9^{\circ} \mathrm{C}\right)$ as in Table 2.

The large change in $\mathrm{T}_{\mathrm{m}}$ suggests the binding affinities of the ruthenium complexes with DNA are very strong [41]. From Table 2, it may be observed that varying degrees of $\Delta \mathrm{T}_{\mathrm{m}}\left({ }^{\circ} \mathrm{C}\right)$ were achieved by the complexes depending on their auxiliary ligand and polypyridyl ligand end group. The largest change $\left(\Delta^{\circ} \mathrm{C}\right)$ was observed by the complexes with the phenanthroline auxiliary ligands $\left(15.4-6.6^{\circ} \mathrm{C}\right)$, while the complexes with the bipyridine auxiliary ligands resulted in a $\left(\Delta \mathrm{T}_{\mathrm{m}}\right)$ increase range of $11.9-5.3^{\circ} \mathrm{C}$. The large increase in $\mathrm{T}_{\mathrm{m}}$ result is typical of complexes which intercalate between the base pairs of DNA, stabilizing the duplex structure. The potential of the main polypyridyl ligands can also be observed and marked differences can be seen by end groups and positional changes. The CPIP and FPIP terminated complexes stabilized the DNA core and raised the melting temperature by $15.4^{\circ} \mathrm{C}$ and $15.2^{\circ} \mathrm{C}$ for the complexes with the phenanthroline auxiliary ligand. The NPIP and BPIP of the same series of complexes producing smaller $\mathrm{T}_{\mathrm{m}}$ values theses are still within the range expected of intercalative complexes. Overall the best produced $\mathrm{T}_{\mathrm{m}}$ values came from the complexes bound to the phenanthroline auxiliary ligands followed closely by the bipyridine complexes producing large $\mathrm{T}_{\mathrm{m}}$ values also. The experimental results the complexes containing the bipyridine auxiliary ligands, also suggests an intercalative binding mode.

The large increase in $T_{m}$ result is typical of complexes which 
intercalate between the base pairs of DNA, stabilizing the duplex structure. The binding $\mathrm{T}_{\mathrm{m}}$ results are comparable to those of structurally similar ruthenium (II) polypyridyl complexes such as; [Ru $(\text { phen })_{2}$ (APIP) $]^{2+}$ (1) and $[\text { Ru(phen })_{2}($ HAPIP $\left.)\right]^{2+}(2)$; (whereby (APIP) $=2$-(2-Aminophenyl)imidazo $\quad[4,5-f][1,10]$ phenanthroline (polypyridyl ligand with an ortho substituted amine group) and HAPIP = 2-(2-Hydroxyl-5-aminophenyl)imidazo [4,5-f] [1,10]-Phenanthroline (meta substituted amine group and ortho substituted hydroxyl group). Their DNA-binding behavior was analysed by electronic absorption titration and thermal denaturation studies yielding $\mathrm{K}_{\mathrm{b}}$ values for the complexes of $3.38 \times 10^{5} \mathrm{M}^{-1}$ and $3.93 \times 10^{5} \mathrm{M}^{-1}$ respectively. The observed change of melting temperatures $\left(\Delta \mathrm{T}_{\mathrm{m}}\right)$ in the presence of complexes 1 and 2 are $68.4^{\circ} \mathrm{C}\left(\Delta=+7.8^{\circ} \mathrm{C}\right)$ and $71.9^{\circ} \mathrm{C}$ $\left(\Delta \mathrm{T}_{\mathrm{m}}=+11.3^{\circ} \mathrm{C}\right)$ respectively Liu et al. also synthesised another two promising ruthenium (II) complexes $\left[\mathrm{Ru}(\mathrm{bpy})_{2}(\mathrm{DBHIP})\right]^{2+}(1)$ and $[\mathrm{Ru}$ (phen) $\left.)_{2}(\mathrm{DBHIP})\right]^{2+}(2)$; $\quad$ (where DBHIP $=$ (2-(3,5-dibromo-4-hydroxyphenyl)imidazo[4,5-f] $[1,10]$ phenanthroline (polypyridyl ligand with two meta substituted $\mathrm{Br}$ groups and a para substituted hydroxyl group)). Both complexes increased the melting temperatures $\left(\Delta \mathrm{T}_{\mathrm{m}}\right)$ in the presence of DNA as follows; (1) $75.2^{\circ} \mathrm{C}$ and (2) $76.8^{\circ} \mathrm{C}$ respectively with an initial DNA $\mathrm{T}_{\mathrm{m}}$ of $68.9^{\circ} \mathrm{C}$ [41].

Furthermore two ruthenium (II) complexes with a benzofuran group instead of a disubstituted benzene group of the polypyridyl type ligands synthesised in this thesis have shown comparable results. Du et al. synthesised $\left[\mathrm{Ru}(\mathrm{bpy})_{2}(\mathrm{bfipH})\right]^{2+}(1)$ and $\left[\mathrm{Ru}(\mathrm{phen})_{2}(\mathrm{bfipH})\right]^{2+}$ (2) (where bfipH $=2$-(benzofuran-2-yl)imidazo[4,5-f] [1,10] phenanthroline) which produced intrinsic binding constants, $\mathrm{K}_{\mathrm{b}}$ of $4.59 \times 10^{6} \mathrm{M}^{-1}$ and $6.37 \times 10^{6} \mathrm{M}^{-1}$ determined by the McGheeVon Hippel (MVH) model [42]. Also these two complexes [Ru(bpy $\left.)_{2}(\mathrm{bfipH})\right]^{2+}(1)$ and $[\mathrm{Ru}$ (phen) $\left.)_{2}(\mathrm{bfipH})\right]^{2+}$ (2) presented thermal melting curves with a $\mathrm{T}_{\mathrm{m}}$ within a similar range to the complexes analysed in this chapter; $\mathrm{T}_{\mathrm{m}}=78.8^{\circ} \mathrm{C}$ and $79.5^{\circ} \mathrm{C}$ for complexes 1 and 2 respectively, at the exact same concentration ratio $[\mathrm{Ru}] /[\mathrm{DNA}] 1: 10$. The large increases in $\mathrm{T}_{\mathrm{m}}$ of DNA with the two Ru(II) complexes $\left(\Delta \mathrm{T}_{\mathrm{m}}\right.$ is 18.4 and $19.1^{\circ} \mathrm{C}$ for 1 and 2, are comparable to that observed for classical intercalators). Other significantly well-known complexes have had the melting points of DNA increased by 13 and $16^{\circ} \mathrm{C}$ for ethidium bromide (EB) and $\Delta$-[Ru (phen)2(dppz) $]^{2+}$, respectively [42].

The effects of the two renowned antitumour ruthenium(III) complexes; NAMI (sodium trans-(dimethylsulfoxide)(imidazole)tetrachloro ruthenate(III)) and RAP (dichloro-1,2-propylenediamine tetraacetate ruthenium(III)) $\mathrm{Ru}(\mathrm{III})$ ) have also been reported in the literature. One of these compounds, NAMI is endowed with potent antimetastatic properties and has been analysed to determine its thermal denaturation profile with calf thymus DNA. It was established from the experimental data that both NAMI and RAP complexes induce a slight stabilisation of the double helix $\Delta \mathrm{T}_{\mathrm{m}}$ for NAMI is $+2.5^{\circ} \mathrm{C}$ and RAP is $+1{ }^{\circ} \mathrm{C}$ [38]. Notably the effects induced by these significant complexes on the melting profiles of calf thymus DNA are smaller than those produced in vitro by the novel Ru complexes in this study, as expected due to their different mode of action. The ruthenium complexes analysed by $\mathrm{L}$. Messori et al. acknowledged that the interactions do not fully represent the molecular basis for the biological effects of ruthenium complexes; however they do help establish that DNA constitutes a reasonable target for these biologically active ruthenium (III) complexes, especially since some ruthenium (III) complexes have previously been shown to accumulate preferentially in the cell nucleus $[43,44]$.

\subsection{DNA binding studies trends and correlations}

The binding constants for the ruthenium complexes presented in Table 2 elucidated the roles of the ancillary ligand, end group and regioisomers on both the spectroscopic and biological effect via DNA interaction. Variation of the auxiliary ligands has been shown to of huge interest when attempted to tailor the electronic properties of the complexes, however when accessing the biological effect of DNA interaction variation in binding modes prevent trends and correlations being presented as the auxiliary ligand effect far outweighs any effect that would be induced due to end-group of positions changes on the intercalative ligand. Apart from the structural variation that will result from the planarization of polypyridyl ligands with the variation of the auxiliary ligand, size and steric issues will also play a part in restricting DNA binding. The variation of auxiliary ligand plays a large role in the mode of action inducing a competitive dual effect being the planarization of the intercalative ligand due to delocalisation of electronic and the macroscopic effect of the size and steric effect of the inclusion of the larger auxiliary ligand. It has been shown that the size of the auxiliary ligand can play a large role in inhibiting intercalative effects and from the CD data it is obvious the larger auxiliary ligands have a profound effect on the induced CD changes [30]. The DNA studies have shown that the most effective series of complexes for strength of binding, modification of the both the base stacking and increasing denaturation temperature was the $\left[\mathrm{Ru}(\mathrm{phen})_{2} \mathrm{~L}\right]^{2+}$ complexes. As such the correlations shown have been confined to this series as they have shown the largest variation in DNA interaction with systematic variation of structural parameters.

The observed melting temperature in the presence of the $[\mathrm{Ru}$ (phen) $\left.)_{2} \mathrm{~L}\right]^{2+}$ complexes successively increased in the order of BPIP, NPIP, FPIP and CPIP. In particular it is CPIP and FPIP that stabilize the DNA helix the best resulting in the largest increase of the melting point. These two specific complexes $\left[\mathrm{Ru}(\mathrm{phen})_{2} p-\mathrm{CPIP}\right]^{2+}$ and $[\mathrm{Ru}$ (phen) ${ }_{2} p$-FPIP $]^{2+}$ also affected the CD spectrum of DNA with the most pronounced induced peak developing at $265 \mathrm{~nm}$. When you plot the change in the CD spectrum ( $275 \mathrm{~nm}$ reduction and $265 \mathrm{~nm}$ growth) as a function of the increase in melting temperature $\left(\mathrm{T}_{\mathrm{m}}\right)$ the graph is shown in Fig. 6 is resultant.

Fig. 6 shows the $\Delta \mathrm{CD}$ intensity of $\left[\mathrm{Ru}(\mathrm{phen})_{2} p-\mathrm{L}\right]^{2+}$ complexes whereby $\mathrm{L}$ is the para substituted polypyridyl ligands consisting of the four main end groups (FPIP, CPIP, NPIP and BPIP) as a function of the $\Delta \mathrm{T}_{\mathrm{m}}$ generated by complexes in the presence of DNA. This graph correlates the change in the thermal denaturation temperature $\left(\Delta \mathrm{T}_{\mathrm{m}}\right.$ from DNA temperature) produced by each complex with the difference in epilicity intensity of the induced peak $(\Delta C D)$ at $275 \mathrm{~nm}$. The increased size of the induced $\mathrm{CD}$ peak follows the same marked effect as observed in the thermal denaturation $\left(\mathrm{T}_{\mathrm{m}}\right)$ results of the complexes bound to DNA. From the thermal denaturation results (Table 2) the $[\mathrm{Ru}$ (phen $\left.)_{2} p-\mathrm{CPIP}\right]^{2+}$ complex showed the largest $\mathrm{T}_{\mathrm{m}}$ of $80^{\circ} \mathrm{C}\left(\Delta \mathrm{T}_{\mathrm{m}}\right.$ of $+15.4^{\circ} \mathrm{C}$ ) and it also generated the largest induced peak on the DNA CD spectrum as shown in Fig. 6, followed closely by the FPIP terminated complex (Table 2). The evidence shows that the phen complexes containing the most electron withdrawing group $\mathrm{NO}_{2}$ (NPIP) and least electron withdrawing group i.e. bromine (BPIP) produced the smallest

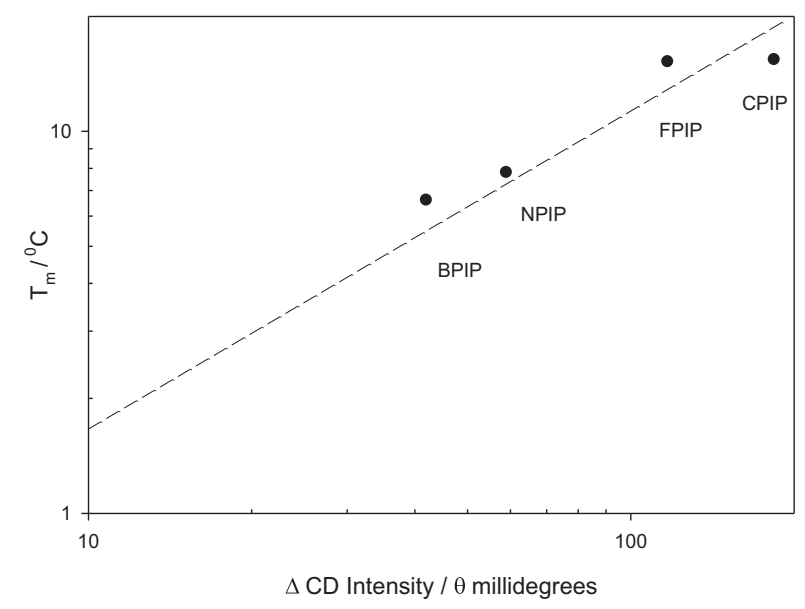

Fig. 6. The $\Delta \mathrm{CD}$ intensity of $\left[\mathrm{Ru}(\mathrm{phen})_{2} p-\mathrm{L}\right]^{2+}$ complexes plotted versus the $\Delta \mathrm{T}_{\mathrm{m}}$ (logarithmic scale) (whereby $p$-L = para substituted FPIP, CPIP,NPIP and BPIP). 
increase in the DNA core temperature $\left(\Delta=+7.8^{\circ} \mathrm{C}\right.$ and $\left.6.6^{\circ} \mathrm{C}\right)$ while also generating the least effective induced peak in the $\mathrm{CD}$ spectra at the same DNA: complex ratios. This would suggest that although the $\mathrm{NO}_{2}$ and $\mathrm{Br}$ complexes are the best intercalators and also that the mode of action for the more polar main ligands is different in nature that for the more electronically neutral FPIP and CPIP.

It has been illustrated that the imidazole stretching frequency as measured by Raman spectroscopy could be used a measure of the electronic coherence across the imidazole bridge of the main intercalative ligand [45]. This increased electron density would create the planarised form of the ligand and also the variation in stretching frequency can be seen as an accurate measure of the rotational and steric freedom. If the binding constant of the complexes, when unhindered by the auxiliary ligand size, is directly related to the planarity of the intercalated ligand, then it would be expected that the Raman frequency would be well correlated with the binding constant. Fig. 7 shows a plot of the Raman frequency as a function of the binding constant for the phen and bpy series.

It is evident that the parameters plotted in the graph in Fig. 7 are well-defined, the bpy as mentioned earlier show as invariance in binding constants with the changing of the end-groups however the phen series show a gradual increase in the binding affinity as the imidazole ring stretch in strengthened.

\subsection{In vitro cytotoxicity}

A preliminary cellular viability screen was performed on the parasubstituted complexes to test efficacy against both normal and tumour based cell lines. The para-substituted complexes were selected following the DNA binding constants and thermal denaturation results which suggested that the para-substituted complexes show stronger interaction with DNA over the meta and ortho counterparts. The cell lines employed; A375 (Skin Cancer), HeLa (Cervical Cancer), A549 (Lung Cancer), Beas2B (Lung Normal Cell) and MCF-7 (Breast Cancer), were chosen to reflect many different target organs and cell type. All viability levels were monitored with the aid of the MTT assay.

The calculated IC50 values are presented in Table 3, as can be seen all the tested complexes displayed promising toxicity levels with variations observed between both, tumour and normal lines and target organ. Most of the complexes were noted to be more effective after the longer time point exposure of $96 \mathrm{~h}$, as evident by the lower IC50 values calculated, indicating that the complexes take in excess of $24 \mathrm{~h}$ to achieve greater cytotoxic effects. It is postulated that, based on the DNA intercalation studies, the complexes will bind to DNA and most likely cause fragmentation interrupting the cell cycle and ultimately result in cell death. This increase in cytotoxicity over time may be a direct result

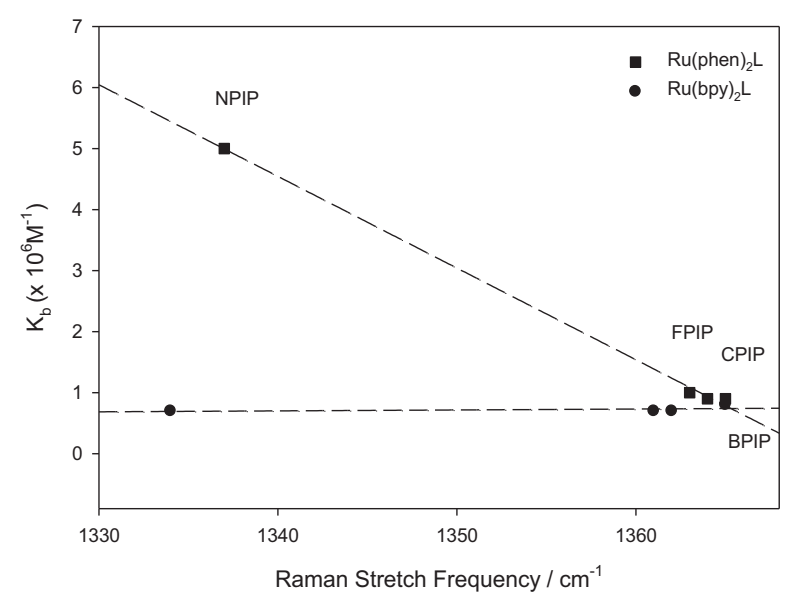

Fig. 7. The imidazole stretch frequency of $\left[\mathrm{Ru}(\mathrm{phen})_{2} p-\mathrm{L}\right]^{2+}$ complexes plotted versus the binding constant $\left(\mathrm{K}_{\mathrm{b}}\right)$ whereby $p$-L = para substituted FPIP, CPIP,NPIP and BPIP. of their mode of action or the required time for the complex to enter the cell and localise at the site of action the DNA containing nucleus, but further more detailed testing would be required to verify this and to determine the exact mechanism of action of the complexes. Interestingly the complexes were noted to be most effective when tested on the A375 cell line, a dermal cancer cell line, with the IC50 values a factor of 10 lower for all the complexes indicating that the complexes may hold promise in the treatment of dermal cancers. When compared to the normal cell control some complexes showed a lower IC50 value in the tumour derived cell lines than that of the normal BEAS2B line indicating a higher degree of efficacy in tumour lines than that of the normal cells. When compared to a commercially utilised chemotherapeutic of similar structure and function, such as cisplatin, these complexes show excellent promise. Studies have shown that cisplatin requires longer incubation times in vitro to elicit the full effect, with IC50 values in immortalised cancer cells decreasing from $166 \mu \mathrm{M}$ after $24 \mathrm{~h}$ exposure to $4.81 \mu \mathrm{M}$ after $96 \mathrm{~h}$ exposure reported [46]. In all of the complexes tested here, in all cells lines, the IC50 values decreased dramatically with increased exposure time indicating that the ruthenium complexes efficacy increases with exposure time. In all of the complexes tested here, in all cells lines, the IC50 values decreased dramatically with increased exposure time indicating that the ruthenium complexes efficacy increases with exposure time. The mechanism of action and further biological investigation of the compounds are ongoing. The DNA intercalation studies have shown that the complexes intercalate with DNA suggesting that their primary mechanism of action will be that of DNA damage, interestingly it was only the full complexes that were noted to intercalate and not the free ligands. This would suggest the presence of the ligand are not significant contributors to the overall toxicity but rather act as a targeting moiety to improve uptake of the ruthenium complexes. To verify this isolated ligand exposures were employed on selected cell lines yielding IC50 values (Table 4) although they did exhibit cytotoxicity, the IC50 values estimated for ligands were not comparable to the complexes and as such it is postulated in the complex form they do not significantly contribute to the overall observed cytotoxicity levels of the complexes. The results achieved would be of a comparable magnitude to that reported recently by Wan et al. [6], Tang et al. [8] and Zhang et al. [4] for similar structured complexes.

\section{Conclusion}

The binding properties of a series of novel ruthenium complexes to DNA of the general structure; $\left[\mathrm{Ru}(\text { phen })_{2} \mathrm{~L}\right]^{2+}$ and $\left[\mathrm{Ru}(\mathrm{bpy})_{2} \mathrm{~L}\right]^{2+}$ whereby $\mathrm{L}$ is a planar aromatic polypyridyl ligand (CPIP, FPIP,NPIP and BPIP) were investigated using various biophysical techniques. Regioisomers were biologically evaluated of three series of complexes of the structure; $\left[\mathrm{Ru}(\mathrm{phen})_{2} x \text {-CPIP }\right]^{2+}$ and $\left[\mathrm{Ru}(\mathrm{bpy})_{2} x \text {-CPIP }\right]^{2+}$ where $x=$ para, meta and ortho. As previously mentioned it is thought that the main target for ruthenium (II) complexes is DNA and their direct binding to DNA consequently resulting in DNA damage so three biophysical techniques were chosen to determine the potential of these novel complexes; UV/Vis DNA titrations, circular dichroism and thermal denaturation. The conclusions drawn from the biological experimental suggests the significance of the auxiliary ligand; especially 1,10-phenanthroline has on the binding constants $\left(K_{b}\right)$. The results suggest that the $\left[\mathrm{Ru}(\mathrm{phen})_{2} \mathrm{~L}\right]^{2+}$ complexes intercalate more efficiently and are attracted to DNA even more so than $\left[\mathrm{Ru}(\mathrm{bpy})_{2} \mathrm{~L}\right]^{2+}$ analogues.

In spite of their structural similarities the overall DNA action of the complexes differ significantly from each other especially when looking at them from end group and positional effect. The aldehyde and nitrile group end on the polypyridyl ligand exhibited more effective DNA binding via an intercalative mode when combining the binding constant $\left(\mathrm{K}_{\mathrm{b}}\right)$, thermal denaturation $\left(\mathrm{T}_{\mathrm{m}}\right)$ values and pronounced induced $\mathrm{CD}$ peak on the chiral DNA peak.

DNA binding constants show all types of binding, covalent and non- 
Table 3

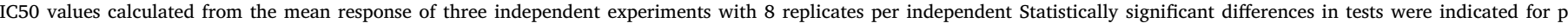

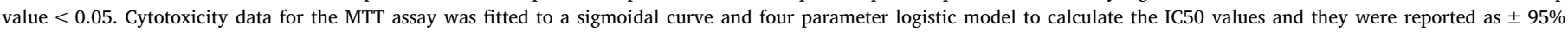
confidence interval. All quoted IC50 values were estimated using GraphPad Prism 7.0.

\begin{tabular}{|c|c|c|c|c|c|c|c|c|c|}
\hline Compound/Cell lines & A375 $24 \mathrm{~h} \mu \mathrm{M}$ & A375 $96 \mathrm{~h} \mu \mathrm{M}$ & HeLa $24 \mathrm{~h} \mu \mathrm{M}$ & HeLa $96 \mathrm{~h} \mu \mathrm{M}$ & A549 $24 \mathrm{~h} \mu \mathrm{M}$ & A549 $96 \mathrm{~h} \mu \mathrm{M}$ & BEAS2B $24 \mathrm{~h} \mu \mathrm{M}$ & BEAS2B $96 \mathrm{~h} \mu \mathrm{M}$ & MCF-7 $96 \mathrm{~h} \mu \mathrm{M}$ \\
\hline$\left[\mathrm{Ru}(\mathrm{phen})_{2} p \text {-CPIP }\right]^{2+}$ & 11.8 & 2.88 & 283 & 12.6 & 46.5 & 9.56 & 61 & 14.3 & 17.7 \\
\hline$\left[\mathrm{Ru}(\mathrm{phen})_{2} p \text {-NPIP }\right]^{2+}$ & 47.0 & 11.2 & 1370 & 86.4 & 420 & 130 & 486 & 114 & 38.9 \\
\hline$\left[\mathrm{Ru}(\mathrm{phen})_{2} p \text {-FPIP }\right]^{2+}$ & 24.8 & 9.52 & 265 & 90.9 & 531 & 201 & 407 & 67.8 & 163 \\
\hline$\left[\mathrm{Ru}(\mathrm{phen})_{2} p \text {-BPIP }\right]^{2+}$ & 34.6 & 12.6 & 77.2 & 45.2 & 38.5 & 12.1 & 111 & 44.5 & 20.9 \\
\hline$\left[\mathrm{Ru}(\mathrm{bpy})_{2} p \text {-CPIP }\right]^{2+}$ & 85.2 & 8.11 & 281 & 45.4 & 164 & 28.3 & 262 & 32.5 & 64.4 \\
\hline$\left[\mathrm{Ru}(\mathrm{bpy})_{2} p \text {-NPIP }\right]^{2+}$ & 40.3 & 26.3 & 322 & 38.9 & 223 & 346 & 105 & 21.0 & 86.5 \\
\hline$\left[\mathrm{Ru}(\mathrm{bpy})_{2} p \text {-FPIP }\right]^{2+}$ & 99.2 & 38.5 & 1580 & 285 & 765 & 1140 & 258 & 55.4 & 377 \\
\hline$\left[\mathrm{Ru}(\mathrm{bpy})_{2} p \text {-BPIP }\right]^{2+}$ & 73.2 & 21.4 & 203 & 104 & 228 & 139 & 142 & 39.2 & 283 \\
\hline
\end{tabular}

Table 4

IC50 values $(\mu \mathrm{M})$ for ligands were calculated from the mean response after a $24 \mathrm{~h}$ exposure of three independent experiments with 8 replicates per independent. Statistically significant differences in tests were indicated for $\mathrm{p}$ value $<0.05$. Cytotoxicity data for the MTT assay was fitted to a sigmoidal curve and four parameter logistic model to calculate the IC50 values and they were reported as $\pm 95 \%$ confidence interval. All quoted IC50 values were estimated using GraphPad Prism 7.0.

\begin{tabular}{llll}
\hline Ligand & HeLa $(\mu \mathrm{M})$ & BEAS2B $(\mu \mathrm{M})$ & A549 $(\mu \mathrm{M})$ \\
\hline FPIP & 300 & 40 & 130 \\
CPIP & 270 & 760 & 290 \\
BPIP & 10 & 10 & 11 \\
\hline
\end{tabular}

covalent, intercalating and electrostatic binding and screened the potential of all the novel ruthenium complexes synthesised. The circular dichroism experiment backed up the $\mathrm{K}_{\mathrm{b}}$ values and allowed the complexes with the most potential to be focused on. Thermal denaturation finalised and reinforced the intercalative ability of the ruthenium complexes. Similar trends seen in the circular dichroism were observed in the thermal denaturation study establishing that the complexes with the phen auxiliary ligands giving the best results. From the end group point of view of the nitrile terminated polypyridyl ligands stabilized the DNA core the greatest, followed by the aldehyde terminated ligands, the nitro group and lastly the bromine terminated ligand. It becomes apparent that the selection in the end group of the polypyridyl ligand has profound effect on the DNA binding ability and by association the complexes potential as a therapeutic candidate. It has been shown that the planarity of the polypyridyl ligand, as measured by examination of the vibrational spectrum, is directly relatable to the binding constant $\left(\mathrm{K}_{\mathrm{b}}\right)$. It is theorised that the ability of the Raman spectrum to take into account steric and electronic changes in the intercalative polypyridyl ligand via electron density variations allows the well-defined relationship shown. This only holds for direct substitution on the polypyridyl ligand as auxiliary ligand change introduces its own steric hindrances and hence varied the mode of interaction.

All the combined techniques (UV/Vis, fluorescence, circular dichroism and thermal denaturation) confirms, that not only does chemical structure of the main polypyridyl ligand but the auxiliary ligand can have a profound effect on both the binding affinity and mode.

The in vitro screening revealed that the produced complexes were active in the micro molar concentration region and displayed good affinity for tumour derived lines with a heightened effect in the dermal cancer model than all other target organs tested. In general, the efficacy of the tested complexes was noted to increase dramatically with increased exposure time indicating that these complexes require time in a cellular environment to elicit their true potential with is postulated to be via DNA intercalation inducing subsequent damage ultimately resulting in cell death. The preliminary cytotoxicity findings presented here highlight the potential of these complexes and warrant further more detailed studies to determine the exact mechanism of action in vitro.

\section{Acknowledgements}

The Authors would like to thank the Dublin Institute of Technology for ABBEST scholarship funding.

\section{Appendix A. Supplementary data}

Supplementary data to this article can be found online at https:// doi.org/10.1016/j.jinorgbio.2018.01.018.

\section{References}

[1] L. Zeng, O. Gupta, Y. Chen, E. Wang, L. Ji, H. Chao, Z.S. Chen, Chem. Soc. Rev. 46 (2017) 5771-5804.

[2] K.E. Erkkila, D.T. Odom, J.K. Barton, Chem. Rev. 99 (9) (1999) 2777-2796.

[3] http://theralase.com/pressrelease/theralase-anti-cancer-technology-presentedinternational-conference/.

[4] S. Zhang, Q. Wu, H. Zhang, Q. Wang, X. Wang, W. Mei, X. Wu, W. Zheng, J. Inorg. Biochem. 176 (2017) 113-122.

[5] S. Swavey, K. Morford, M. Tsao, K. Comfort, M.K. Kilroy, J. Inorg. Biochem. 175 (2017) 101-109.

[6] D. Wan, S.H. Lai, C.C. Zeng, C. Zhang, B. Tang, Y.J. Liu, J. Inorg. Biochem. 173 (2017) 1-11.

[7] O. Mazuryk, M. Lomzik, D. Martineau, M. Beley, M. Brindell, G. Stchel, P.C. Gos, Inorg. Chim. Acta 443 (2016) 86-90.

[8] B. Tang, B.J. Han, D. Wan, S.H. Lai, X.Z. Wang, C. Zhang, C.C. Zeng, Y.J. Liu, Transit. Met. Chem. 42 (5) (2017) 373-386.

[9] G.B. Jiang, Y.Y. Xie, G.J. Lin, H.L. Huang, Z.H. Liang, Y.J. Liu, J. Photochem. Photobiol. B Biol. 129 (2013) 48-56.

[10] G. Li, L. Sun, L. Ji, H. Chao, Dalton Trans. 45 (34) (2016) 13261-13276.

[11] M.R. Gill, J.A. Thomas, Chem. Soc. Rev. 41 (8) (2012) 3179-3192.

[12] L. Salassa, Eur. J. Inorg. Chem. (2011) 4931-4947.

[13] H. Chao, R.H. Li, C.W. Jiang, H. Li, L.N. Ji, X.Y. Li, J. Chem. Soc. Dalton Trans. (2001) 1920-1926.

[14] H. Chao, H. Li, R.H. Li, J.Y. Zhou, L.N. Ji, Polyhedron 19 (2000) 1975-1983.

[15] J. Liu, W.J. Mei, L.J. Lin, K.C. Zheng, H. Chao, F.C. Yun, L.N. Ji, Inorg. Chim. Acta 357 (2004) 285-293.

[16] H. Xu, K.C. Zheng, L.J. Lin, H. Li, Y. Gao, L.N. Ji, J. Inorg. Biochem. 98 (2004) 87-97.

[17] X. He, L. Zeng, G. Yang, L. Xie, X. Sun, L. Tan, Inorg. Chim. Acta 408 (2013) 9-17.

[18] A. Bencini, V. Lippolis, Coord. Chem. Rev. 254 (2010) 2096-2180.

[19] J. Reedijk, Platin. Met. Rev. 52 (1) (2008) 2-11.

[20] T. Gianferrara, I. Bratsos, E. Alessio, Dalton Trans. (2009) 7588-7598.

[21] L.N. Ji, X.H. Zou, J.G. Liu, Coord. Chem. Rev. 216-217 (2001) 513-536.

[22] L.F. Tan, H. Chao, X.H. Zou, J.G. Liu, Polyhedron 26 (2007) 3029-3036.

[23] L.F. Tan, H. Chao, H. Li, Y.J. Liu, B. Sun, W. Wei, L.N. Ji, J. Inorg. Biochem. 99 (2005) 513-520.

[24] L.F. Tan, F. Wang, H. Chao, Y.F. Zhou, C. Weng, J. Inorg. Biochem. 101 (2007) 700-708.

[25] S. Page, Ed. Chem. 49 (2012) 1.

[26] R.H. Zheng, H.C. Guo, H.J. Jiang, K.H. Xu, B.B. Liu, W.L. Sun, Z.Q. Shen, Chin. Chem. Lett. 21 (2010) 1270-1272.

[27] N.N. Sergeeva, M.D. Marechal, G.M. Vaz, A.M. Davies, M.O. Senge, Bioorg. Med. Chem. Lett. 21 (2011) 4385-4388.

[28] G. Sprintschnik, H.W. Sprintschnik, P.P. Kirsch, D.G. Whitten, J. Am. Chem. Soc. 99 (15) (1977) 4941-4954.

[29] S. Shuo, J. Liu, J. Li, K.C. Zheng, C.P. Tan, L.M. Chen, L.N. Ji, Dalton Trans. (2005) 2038-2046.

[30] M. Sirajuddin, S. Ali, A. Badash, J. Photochem. Photobiol. B Biol. 124 (2013) 1-19.

[31] W. Zhong, J.S. Yu, Y. Liang, K. Fan, L. Lai, Spectro. Chimica. Acta. A 60 (2004) 2985-2992.

[32] K.R. Fox, Drug-DNA Interaction Protocols, Springer Protocols, Methods in Molecular Biology, 2nd ed, Humana Press, 2010.

[33] L.M. Chen, J. Liu, J.C. Chen, C.P. Tan, S. Shi, K.C. Zheng, L.N. Ji, J. Inorg. Biochem. 
102 (2008) 330-341.

[34] K. Nakamoto, M. Tsuboi, G.D. Strahan, Drug-DNA Interactions Structures and Spectra, Wiley, New Jersey, 2008.

[35] B. Norden, A. Rodger, T. Dafforn, Linear Dichroism and Circular Dichroism, a Textbook on Polarized Light Spectroscopy, RSC publishing, UK, 2010.

[36] Y.J. Jang, G.Y. Yeo, B. Park, S.K. Kim, Biophys. Chem. 158 (2011) 38-45.

[37] X.L. Liu, J.L. Lu, Y.D. Chen, L. Li, D.S. Zhang, Inorg. Chim. Acta 379 (2011) 1-6.

[38] R.B. Nair, E.S. Teng, S.L. Kirkland, C.J. Murphy, Inorg. Chem. 37 (1) (1998) $139-141$.

[39] J.Z. Wu, B.H. Ye, L. Wang, L.N. Ji, J.Y. Zhou, R.H. Li, Z.Y. Zhou, J. Chem. Soc Dalton Trans. (1997) 1395-1401.

[40] S. Shi, J. Liu, J. Li, K.C. Zheng, X.M. Huang, C.P. Tan, L.M. Chen, L.N. Ji, J. Inorg. Biochem. 100 (2006) 385-395.
[41] Y.J. Liu, Z.H. Liang, Z.Z. Li, J.H. Yao, H.L. Huang, J. Of, Organomet. Chem. 696 (2011) 2728-2735.

[42] K.J. Du, J.K. Wang, J.F. Kou, G.Y. Li, L.L. Wang, H. Chao, L.N. Ji, Eur. J. Med. Chem. 46 (2011) 1056-1065.

[43] L. Messori, A. Casini, D. Vullo, S.G. Haroutiunian, E.B. Dalian, P. Orioli, Inorg. Chim. Acta 303 (2000) 283-286.

[44] D. Frasca, J. Ciampa, J. Emerson, R.S. Umans, M.J. Clarke, Metal-Based Drugs 3 (4) (1996) 197-209.

[45] L. O'Neill, L. Perdisatt, C.M. O'Connor, J. Phys. Chem. A 116 (44) (2012) 10728-10735.

[46] A. Kellett, M. O'Connor, M. McCann, O. Howe, A. Casey, P. McCarron, K. Kavanagh, M. McNamara, S. Kennedy, D. May, P. Skell, D. O'Shea, M. Devereux, Med. Chem. Commun. 2 (2011) 579-584. 